\title{
What do German bank customers want? The importance of customer expectations and the failure of the integral customer advisory service
}

\section{Introductory overview}

The market environment for banks currently faces numerous challenges (Actico 2019, 4). There are three main issues: the low interest rate policy of the European Central Bank, increasing regulation because of the financial and economic crisis starting in 2007, and digitization (Mihm, Wollmann 2018, 6; Grandke $2019,494)$. In recent years, European banks have felt the erosion of earnings due to the flattening interest rate curve because of a high dependency on interest income (Godenrath 2013, 5). In addition, the commission income is stagnating and the regulatory requirements for banks are constantly increasing. Meanwhile, digitization is changing the banking sector fundamentally (Mihm, Wollmann 2018, 6; Grandke 2019, 494). It not only paves the way for new competitors (Kemmer 2017, B6; Fischer 2019b, 3), but also touches the core of banking by changing access and contact options to customers (Wolberg 2017, B5). However, it is not only the general conditions in which banks operate which have changed fundamentally but also the behaviour of bank customers has evolved (Mang 2015, B2). Banking is increasingly done from home, with a particular focus on flexibility and convenience (Capgemini, Efma 2018, 45; Kautz 2018, 4). Nowadays, customers are more informed and more demanding than ever before (Lieberknecht 2019b, B8). If banks do not manage to meet the higher expectations on customer experience, the loyalty of its customers will decrease (Accenture 2016, 2; Quadient 2017, 6).

\footnotetext{
* IUBH International University of Applied Sciences and Saarland University, e-mail: j.hastenteufel@ iubh-fernstudium.de.

* Saarland University (Germany), e-mail: sabrina.kiszka@bank.uni-saarland.de .
} 
It is essential for banks to meet their customers' expectations. Therefore, we will briefly explain the challenges posed to the banking industry. In addition, we will examine the importance of customer expectations in conjunction with customer satisfaction and customer loyalty as well as analysing the downstream economic effects for banks. Based on this, the changing characteristics, behaviours and expectations of German bank customers are considered in order to present the current customer relationship management approach of banks. A study conducted by the authors also examines the requirements on communication, accessibility, pricing and customer advice and the extent to which German banks manage to meet the customer expectations. Moreover, we will consider the perceived customer orientation and the current customer relationship management concept of banks. Finally, we supply some recommendations for banks on how to act in the future.

\section{Current challenges for banks}

\subsection{Low interest rate phase}

After a continuous decline for many years, the interest rate level has now reached an all-time low. The European Central Bank's low interest rate policy in particular is responsible for the decline in interest rates (Waschbusch et al. 2018, 916). This has a three-fold effect on banks' net interest income (Meyer 2016; Kirmße 2017, 297):

- a decrease in the liability margin,

- a decrease in income from the investment of equity,

- restricted possibilities of the maturity transformation.

These effects could initially be offset by longer-term, higher-interest positions, but with their expiry, the malaise of banks is becoming increasingly acute (Waschbusch et al. 2018, 423). The banking sector is therefore suffering from a slow but steady decline in margins (Andrae et al. 2018, 733) which is permanently eroding the banks' earnings (Weidmann 2017, 4; Bocken, Hagedorn 2018, 55).

Naturally, banks whose earnings mainly depend on net interest income are particularly affected by this development (Kirmße 2017, 297). The aforementioned dependency is very distinct in German banks (Sinn, Schmundt 2016, 9) and has been decreasing very slowly over the past years (Sinn, Schmundt 2018, 10-11). At the end of 2018, an average of $72 \%$ of the income of German banks was generated from their net interest income (Deutsche Bundesbank 2019, 90). At this point, commission-earning business still cannot compensate for the decline in 
What do German bank customers want? The importance of customer expectations...

net interest income, among other things due to the reluctance of Germans to buy securities and the preference for simple, non-lucrative products (Neubacher 2014, 5; Sinn, Schmundt 2018, 10). In particular, banks with high customer deposits face increasing pressure (Schuster, Hastenteufel 2019, 34).

\subsection{Increasing regulation}

In the context of declining earnings and with regulation being the biggest cost driver, bank expenses rise continuously and sustainably (Muller 2019, Lister 2018, 3). An increasing number of regulations, increasing complexity and interdependency of the individual requirements as well as a tight timing of the implementation deadlines, characterizes the current regulatory framework. This manifests itself in one-off implementation costs, ongoing administrative efforts and a narrowing of the business scope due to the need for a higher quality capital base (Kirmße 2017, 298-299). There are also rising personnel costs in the management and control departments (Andrae et al. 2018, 729). For the German banking industry, the total cost of regulation which the banks themselves have to pay is estimated at around nine billion Euros per annum (KPMG 2013, 3). Small banks in particular are disproportionately affected by these costs. Therefore, in Germany it is less about the 'too big to fail' problem than the topic of 'too small to comply' (Sinn, Schmundt 2016, 5). In the near future, a reduction in scope and speed of regulatory requirements is not expected (Andrae et al. 2018, 729).

\subsection{Cost-income ratio}

The combination of a persistent low interest rate phase and increasing regulatory requirements leads to an enormous cost pressure in banks (Vogelgesang 2015, 711; Poppensieker, Schröck 2017, 6). In international comparison, German banks have the highest cost-income ratio, alongside France (Böhmert 2019b, 3). This means that the German banks have been absolute outliers in terms of efficiency for years and therefore have to spend relatively more on income generated than other European banks (n.u. 2019a, 4). It is striking that the German banking industry is characterized by a strong degree of fragmentation, leading to a higher level of competition and therefore one of the reasons for the weakness in profits of German banks (Sinn, Schmundt 2018, 22; Böhmert 2019b, 3).

In view of these current developments, it is worrying that, according to a current study, $72 \%$ of banks do not have an overview of the direct and indirect costs resulting from individual products and processes. This is often due to an insufficiently established internal accounting system. In addition, less than half of the banks have schemes for product profitability assessment. A major problem 
in the German banking industry is therefore a poor and non-transparent cost management (Sleegers 2018, 6), because in the past process efficiency and cost transparency have not been a priority for banks (Pade, Bruch 2016, 52). In the recent past, there have only been minor improvements in this regard (Sinn, Schmundt 2018, 13) so that cost efficiency continues to stagnate (Guindos 2019, 3; Leichsenring 2019b). Concrete cost saving plans usually fail due to a lack of will or a lack of strength of implementation. It is not enough to pass on the costs incurred to the customer (Ili, Lichtenthaler 2017, 23).

A rapid improvement in the tense situation is not in sight, so that the banks' already weak profitability will continue to decline due to the increasing pressure on the interest income (Kautz 2018, 5). This is also the result of the Deutsche Bundesbank's stress test carried out in 2019 (BaFin 2019; Sleegers 2019). With the looming persistence of historically low interest rates, a further significant decline in the profitability of the German banking industry is very likely in the future. It should be noted that German banks wrongly expected a reversal of the trend in their planning; they anticipated rising interest rates and a growing annual surplus. However, from now on banks will have to consider the low interest rate phase as the new normality (Lister 2018, 5). In summary, when it comes to the profitability of banks, the traffic light is already dark yellow with the risk of switching to red (Waschbusch et al. 2018, 916). Thus, a current study assumes that one in ten European banks could be threatened with closure within the next couple of years (n.u. 2019, 7).

\subsection{New competitors}

Compared to other industries, the banking sector was very early affected by the effects of digitization (Dölle 2017). This has created new providers of financial services that have intensified the competition for established credit institutions (Freiling 2019, 936). In addition to falling interest rates, the cost-effective business models of digital competitors have a negative impact on the margin of the banks (Andrae et al. 2018, 733). The declining profitability of their previous business models therefore represents the central challenge for banks (Andrae et al. 2018,733 ). A major problem is the historically grown, very complex and outdated software and hardware landscape of banks, whose conversion will require high investments (Kirmße 2017, 300). However, these investments have not been made sufficiently in the past. This is particularly tricky for banks because customers place the highest demands on a bank's technical infrastructure (Duttenhöfer 2019). In this regard, fintechs have an advantage because they are technologically much more advanced than traditional branch banks (Holtermann, Atzler 2019). Added to this is the innovation and flexibility of digital competitors (Kuhn 2016, B6) 
What do German bank customers want? The importance of customer expectations...

which enables them to offer customer-centric and innovative solutions quickly and cost-effectively with the aim of improving the customer experience (Kiss, Vuckovic 2019, 74). Fintechs mostly develop their services from a customer perspective (Kuhn 2016, B6). Therefore, the products may be essentially the same, but for many customers factors such as:

- simplicity,

- speed,

- convenience,

- availability

make a significant difference (Duttenhöfer 2019; Flesch, Kohlleppel 2019, 709). In addition, fintechs manage to bring their products to the customer in an innovative and understandable way that creates a perceptible benefit for them. They usually specialize in a specific business area of banks, such as payment transactions or wealth management, and specifically offer low-cost digital solutions (Andrae et al. 2018, 730). Fintechs can therefore convince customers with a better priceperformance ratio (Wilken, Lehr 2017, B4). In this context, it is questionable how long banks can continue to offer products whose perceived quality and, in particular, costs do not match those of their competitors.

\section{The importance of customer satisfaction and loyalty for banks}

Given the tense situation within the banking industry, it is increasingly important for banks to represent something special from a customer perspective. For successful differentiation in the financial area, qualitative characteristics such as customer proximity and customer trust are crucial (YouGov 2019, 9). The term 'customer proximity' has been expanded for customers through digitization (Kolak 2018), so that both the classic social and local proximity to the customer through personal contacts, as well as the technical proximity such as the ability to access the services of banks at any time must be taken into account (Büschgen, Büschgen 2002, 236). For example, the branch in your pocket can represent proximity from a customer's perspective (Kolak 2018). Therefore, customer proximity nowadays means a reasonable accessibility and high competence rather than just a local presence (Jentsch 2016, 373). Ultimately, customer proximity or customer orientation for banks themselves describes the strategy of fully aligning with the fulfilment of customer requirements (Leichsenring 2019c). It is therefore linked to a comprehensive and continuous determination and ana-lysis of customer expectations (Bruhn 2012, 15). 
It is precisely by meeting customer expectations that an increase in customer satisfaction can be achieved (Bruhn 2016, 7). For this purpose, the confirmation/ disconfirmation paradigm is used to explain the origin of satisfaction (GröppelKlein et al. 2017, 42). Satisfaction results from the comparison of the actual experience made when using a service with a customer-specific comparison standard (Homburg, Stock-Homburg 2016, 20). The degree of fulfilment of customer expectations therefore decides the degree of customer satisfaction (Kotler et al. $2017,169)$. In the comparison process mentioned, it should be noted that emotional processes dominate the cognitive aspects (Griese 2002, 2). If the expectations are met, the customer is satisfied (Keck, Hahn 2006, 76). However, only exceeding expectations can lead to real enthusiasm. However, the paradigm also shows that failing to meet expectations can leave numerous dissatisfied customers.

Those dissatisfied customers not only show a higher tendency to leave, but also engage in negative word of mouth and thus tell a large number of people in their immediate environment about their dissatisfaction (Bruhn 2016, 6). Dissatisfied customers also share their experiences more often than satisfied customers (Krafft 1999, 519). This has become even more relevant in times of social media (Lenz 2015, 509). Social word of mouth in the form of customer reviews is a key factor in many buying decisions these days. In the banking industry, one third of customers in Europe use online recommendation platforms before deciding on buying a banking product (Thieme, Schweiger 2019, 26). Another form of dissatisfaction is direct complaints to a company (Krafft, Götz 2011, 225). The bank should see this as a chance as it offers them the opportunity to draw attention to product or service deficiencies. It also shows that customers whose complaints have been dealt with satisfactorily are subsequently more satisfied than comparable customers who have never had a reason to complain (Gelbrich et al. 2018, 64).

Satisfied customers are willing to use the services of a bank again or even to a greater extent, which leads to a gradual loyalty on the part of the customers (Bruhn 2016, 7-8 and 49). Customer satisfaction is therefore the most important determinant for achieving customer loyalty (Grohmann et al. 2017, 82). From a demand-related perspective, customer loyalty in finance is understood as the degree to which bank customers make an identical decision when choosing a bank due to factual or emotional ties (Hastenteufel 2018). Loyal customers have higher product usage and longer-lasting business relationships, which means they generate a significantly higher return overall (Lister 2018, 28). In addition to the advantages of repurchasing, there is also a potential for cross- and upselling, positive word of mouth communication and a lower price elasticity of demand (Hepp 2008, 107). With increasing satisfaction and loyalty, the customers' willingness to pay also increases (Meffert et al. 2018, 48). Consistent pursuit of the concept of customer satisfaction is therefore associated with competitive advantages for 
What do German bank customers want? The importance of customer expectations...

banks (Krafft 1999, 513-514; Griese 2002, 1). Banks that recognize that a high level of satisfaction results in a high degree of customer loyalty (Homburg et al. 2017, 116; Meffert et al. 2018, 47) should therefore endeavour to always meet or even exceed their customers' expectations (Kotler et al. 2017, 192). Since the perceived quality of service is a key factor for customer satisfaction (Anderson et al. 1994, 53; Bruhn 2016, 8), employees play a central role in achieving customer satisfaction (Stock-Homburg 2016, 298). Moderating variables such as:

- age,

- income,

- variety seeking,

- duration of a customer relationship,

- competitive environment,

- barriers to change

can influence the strength of the relationship between customer satisfaction and loyalty (Homburg, Bucerius 2016, 80), so that customer satisfaction does not always go hand in hand with long-term customer loyalty (Grohmann et al. 2017, 82-83). A change barrier is, for example, the convenience of the customer not wanting the hassle of switching banks (Keck, Hahn 2006, 78).

Customer loyalty also strengthens a bank's credibility and has a positive impact on the perception of bank services, which reduces the general risk of customers moving away (Keck, Hahn 2006, 79). In addition, existing customers support the acquisition of new customers through recommendations. Banks should internalize the fact that satisfied customers are ultimately the best sales employees of a bank (Oberle et al. 2016, 25). Personal re-commendations have gained tremendous importance in recent years through social media (Rankel 2016, 442). Satisfied customers usually encounter possible mistakes of their own banks with a higher tolerance level than dissatisfied customers (Dittrich 2002, 16). In addition, there is the already mentioned lower price elasticity (Reichheld 1997, 65-66). The customer lifetime value therefore often increases with the duration of the customer relationship (Reichheld 1997, 52). In addition, customers' willingness to switch tends to decrease (Spiwoks 2003, 592). Due to the described positive effects, banks with a high level of customer satisfaction and loyalty have higher long-term economic profits. Thus, measures to improve customer satisfaction should not only be seen as cost drivers but also as long-term investments (Anderson et al. 1994, 63).

Customer loyalty can also have a lasting positive impact on a bank's long-term success through cost savings (Vater, Bergmann 2015, 289). Every company has to invest in adver-tising and sales personnel in order to win new customers (Reichheld 1997, 57). Acquiring new customers is therefore related with significantly higher costs than maintaining existing customer relationships (Bruhn 2016, 6). 
Transaction costs such as administration, marketing and consulting costs also decrease with a longer lasting relationship (Mengue Nkoa 2006, 37). Tied customers are more cost-effective (Vater, Bergmann 2015, 289). Customer loyalty, thus, not only leads to a longer generation of profit margins (Weber, 2018), but often also to a gradual increase in the annual profit margins of individual customers over time (Spiwoks 2003, 892).

A large number of studies have shown the positive relationship between customer satisfaction, customer loyalty and a bank's economic success (Finn 2005, 103; Krafft 2007, 327; Homburg, Bucerius 2016, 80; Helmke et al. 2017, 7). Only if banks capture their customers current needs and wishes, customer satisfaction and loyalty can be increased through measures tailored to the customer (Rennhak et al. 2005, 8-9). It is therefore important to focus on the customer experience, because younger customers in particular want to be heard and included (Leichsenring 2019c).

\section{Modern bank customers and their expectations}

\subsection{Bank customers and their changed usage of bank distribution channels}

The issue of customer loyalty is currently a major challenge for banks (Leichsenring 2018). The banking industry is primarily characterized by rising and rapidly changing customer expectations (Aldred 2019; Fischer 2019b, 3). Due to digital change, customer beha-viour has been undergoing a fundamental metamorphosis for several years (Flesch, Hoklleppel 2019, 708; Rohrmeier 2019, B5). Due to digitization, individual transactions are no longer carried out in the branch, but processed directly online by the customers themselves (Grandke 2019, 495). For this reason, the measurable decline in customer frequency within the branches in particular prompted the banks to reorganize their over-the-counter sales (Aldred 2019), because the branch network is a large, historically grown cost component (Brock 2015, 52). Therefore, the immense cost pressure in recent years has required a significant thinning of the branch network (Klink 2019, B9). The use of media channels is increasing, with the customer opting flexibly for the channel that appears to be the simplest and most convenient for his situation (Vogelgesang $2015,712)$. However, this also means that the same customer can have different expectations in different situations (Rohrmeier 2019, B5). According to a current study, at the end of 2019 it was only 13\% of customers across all banking groups in Germany who primarily used the branch for their banking business (Brackert et al. 2019,9$)$. More than half of the customers $(58 \%)$ use almost exclusively a bank's 
What do German bank customers want? The importance of customer expectations...

digital channels and visit the branch at most once a year. The remaining customers regularly use both - stationary and digital channels. Most bank customers therefore want above all a rich digital offer for standardized products as well as the possibility of on-site advice for more complex products (Godenrath 2014, 4). However, around a quarter of customers are willing to do without the branch for lower prices. Today, already over $70 \%$ of all banking customers digitally process transactions (Vishnoi 2019). Contacting the bank is also preferably digital (n.u. 2019d, 102). Especially for the younger generation, digital channels are the most important point of contact for financial questions (Waschbusch et al. 2019, 916). Due to the multiple use, customers expect a high level of digital and mobile convenience (Crealogix 2018, 10). This manifests itself in the expectation to find a fast, uncomplicated and smoothly functioning digital offer (Capgemini, Efma 2018, 45; Grandke 2019, 495). The simplicity and convenience of the products and services offered is crucial both when choosing the bank and when deciding to maintain an existing customer relationship (Capgemini, Efma 2018, 11). Customers want access to all of their bank's services anytime, anywhere and via any device (Lieberknecht 2019a, 28). Younger customers in particular also expect a complete digitization of banking products (Duttenhöfer 2019).

Due to the increased use of online and mobile banking, the personal component of banking also fades into the background (Andrae et al. 2018, 730). This deve-lopment is associated with a tendency towards decreasing customer loyalty (Daum, Degel 2005, 22, Mengue Nkoa 2006, V), which makes it easier for competitors to penetrate existing customer relationships (Richter-Mundani 1999, 253). Nowadays customers often tend to maintain several bank connections at the same time (Godenrath 2019, 4). As a result, banks often lose contact with customers who only have simple products (e.g. a savings or checking account); comparatively lucrative banking and financial services are demanded from other providers, so that those customers are currently causing more costs than revenue for the banks (Terliesner 2019, 13). Only seniors aged 65 and over are still reluctant to use the digital channels and in many cases, they still prefer to visit the branch (Streim et al. 2019). Due to the above-mentioned developments, the branches are mainly used for consulting services (Fischer 2018, 3). However, the importance of advice in the branches tends to decrease overall (Kleine, Jolmes 2019, 246). Especially in the case of products that require explanation, such as retirement provision and property financing, customers are still looking for personal contact with the bank due to the complexity of these products (Deloitte 2018, 8; Hille 2018, 57; Stollarz 2018, B5; Wannhoff 2018, 40; Gros 2019, B3). Figure 1 illustrates this trend. Human interaction will therefore remain important for the customer, especially when making milestone decisions, but digital channels are increasingly at the heart of customers' financial day-to-day life (Deloitte 2018, 19). 


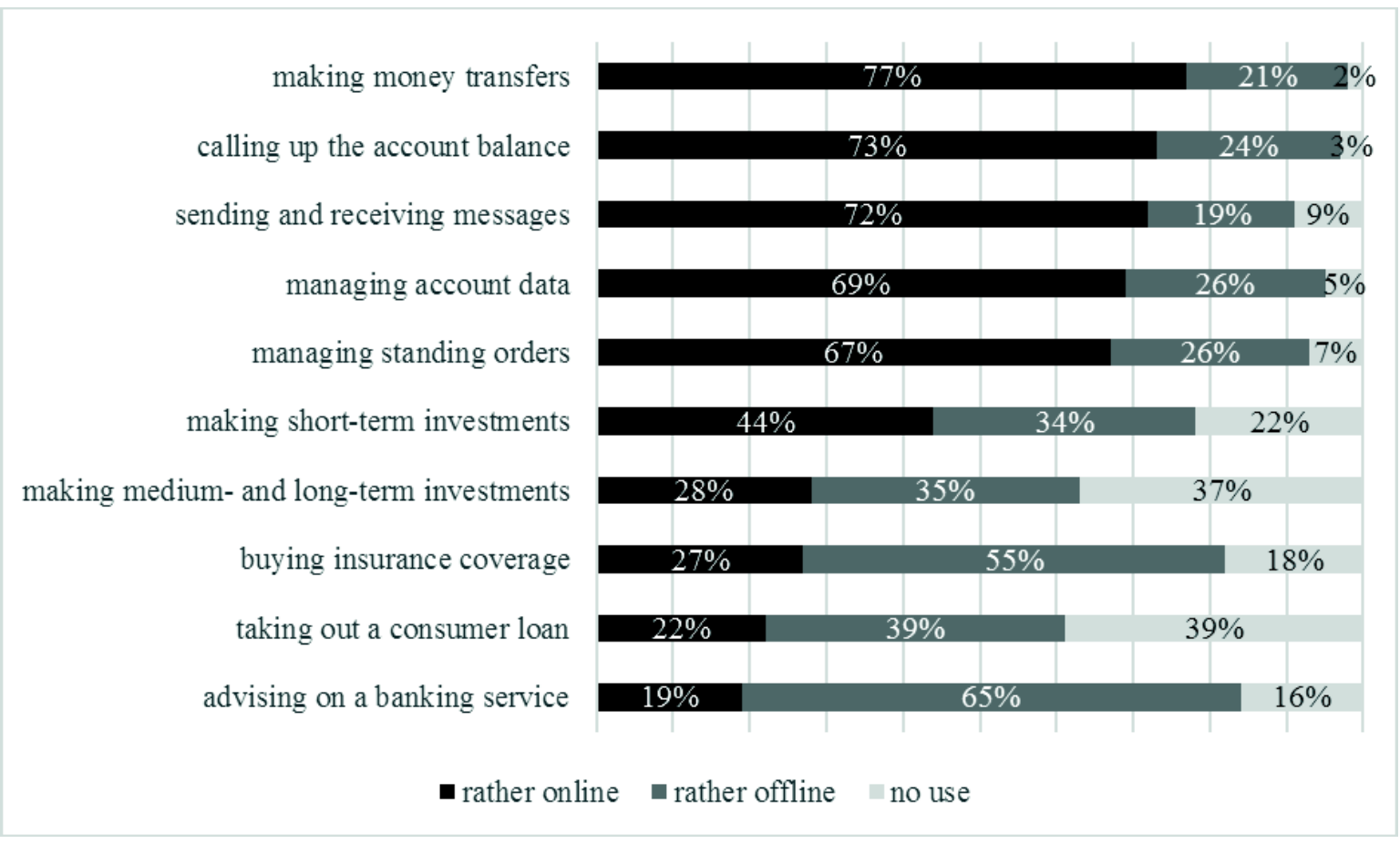

Figure 1. Channel usage preferences for various banking operations in Germany in 2018 (Credit Plus 2018)

\subsection{Rising customer service expectations}

It is becoming increasingly important to satisfy customers' needs immediately, as delays are less and less tolerated (Wolf 2007, 14). The new competitors reinforce the increasing demands (Kiss, Vuckovic, 2019 74). Bank customers are used to the highest level of customization from technology companies such as Google, Amazon, Facebook and Apple. For this reason, they also expect this comfort from their banks (Wenzel 2017). The technology companies are associated with user-friendliness, comfort and reliable service (Wannhoff 2018, 41). The new standards regarding customer expectations are therefore primarily set by these technology companies (Fischer 2019c, 5). As a result, an individualization of customer requests can be observed (Hambrecht, Shefer 2019), so that, in addition to convenience, the personalization of the products offered is an important factor for customers in terms of their long-term loyalty to a bank (Köllnberger et al. 2014, 1). Customers demand proactive offers that are individually tailored to them and their respective living conditions (Capgemini, Efma 2018, 21). For this reason, the customers place high demands on high-quality data analysis and an integrated omnichannel management (Accenture 2018), which enables smooth interactions (Leichsenring 2019c). 
What do German bank customers want? The importance of customer expectations...

However, the Internet helps customers to gain greater market power (Moormann 2001,7$)$ as:

- price transparency is promoted,

- asymmetrical information is reduced,

- changing costs can be reduced (Andrae et al. 2018, 730).

Today's bank customers are well informed, increasingly price-conscious and willing to switch banks, because in their opinion the providers hardly differ (Kuhn 2015, B8). For example, over half of German bank customers have switched banks at least once in the past (Splendid Research 2019). At the same time, customers place high demands on the transparency of financial products (Freiling 2019, 936). In this regard, customers especially criticize hidden fees and non-transparent contracts (Judex 2019, 80). Comparison websites in particular promote the transparency of the market (Thieme, Schweiger 2019, 26). With little effort, customers can determine the best, up-to-date conditions of competing providers and complete transactions with previously unknown banks (Grohmann et al. 2017, 92). The bank with the most attractive offer is selected especially for higher quality products (Bergmann, Vater 2015, 10). Price is one of the most important factors that sets banks apart from their competitors (YouGov 2019, 7). However, this goes hand in hand with an increased level of standards (Reittinger 2019, 359), so that customers expect the best service and the best quality at the lowest price (Grimm, Volk 2005, 378).

The quality of advice is very important (Barkey 2019, 974), but customers want to decide themselves on the type of advice they make use of (Leichsenring 2017). It can be observed that the perceived quality of the products themselves is not only determined in terms of return and performance, but also factors such as the aforementioned transparency and the simplicity of the products are considered to be beneficial (Kuhn 2015, B8). It is not the amount of information, but the understandable presentation of the products that is decisive. Whether a product is concluded depends largely on the advisory skills of the bank employee (Rohrmeier 2019, B5). It is important for customers to be valued and understood by the respective bank (Salesforce 2018, 10; Thole 2019, 270). Customers want their bank to make them feel important (Frank, Mihm 2018, 15). It can be summarized that today's bank custo-mers have a precise idea of what they want and do not hesitate to take the necessary steps to get just that (Accenture 2016, 14). The products must therefore be offered in a way that delights their customers (Capgemini, Efma 2019, 6). On the one hand, banks are striving to increase their advisory and commission business due to the declining interest and trading business (Andrae et al. 2018, 735). On the other hand, the offering of high-quality advisory services is one of the few differentiating features in the competition for customers with new competitors such as fintechs (Kuhn 2016, B6; Becher 2017, 4). This illustrates the relevance 
of a high-quality advisory service for both customer loyalty and the earnings situation in the currently precarious situation of the banks. In the following, we will therefore analyse the customer relationship management concept with which the majority of banks respond to the increasing demands of bank customers.

\section{The concept of holistic advice}

Holistic advice is considered as the ideal in the banking industry (Mihm, Jacobs 2012, 23), which is why most Western European banks use this concept (Wildner 2006, 106). It pursues the goal of looking at the customers in their specific life situation, determining their financial potential and deriving their individual needs from this in order to offer them, demand-actuated products (Klein $2010,198)$. In theory, this approach is an appropriate instrument to meet the increased expectations of customers for individual and personalized advice. The needs and wishes of customers are recorded regularly. This is intended to make the needs of customers transparent so that they can be satisfied with products that are suitable in terms of time and content. This is finally supported by the bank making appropriate contact (Klein 2010, 198). Holistic advice can above all make existing up- and cross-selling potential visible and, at best, this potential can be used (Scherber 2019). Banks are expecting long-term customer loyalty from this relationship management approach, while at the same time exploiting the most important earnings potential of their customers (Wolpers, Appuhn 2006, 143). The goals to be achieved are planned based on market views and the estimated potential for all products (Bartels, Djouimai 2005, 73).

\section{What bank customers want - an empirical approach}

\subsection{Channels and products}

The following section analyses which distribution channels and products the surveyed bank customers use. On average, customers maintain business relationships with two banks. This confirms the increased tendency to use multiple bank connections in parallel. A quarter of the customers (24.97\%) already state that they are customers of at least three banks.

The majority of customers (83.44\%) do not use the bank branch or do so only rarely. An exception is the group of senior citizens from the age of 66 , who has by far the highest frequency of visits. In this customer group, $43.28 \%$ use the branch (otherwise an average of $9.50 \%$ ). The majority of customers use online banking. This also applies for almost half of the senior citizens (46.27\%). Here, the use is 
What do German bank customers want? The importance of customer expectations...

highest in the customer group up to and including 45 years of age (67.39\%). Currently, however, every age group still has potential to increase their use of online banking. In order to tap this potential, customers' existing security concerns must be eliminated. A study by the German Banking Association shows that $52 \%$ of customers still do not find online banking to be completely secure (Bankenverband $2018,9)$. The security concerns are even more evident when using mobile banking. Here, however, the concerns in Germany lie more in the medium of the smartphone itself than in the banking app (Schrader 2019, 3). The established structure corresponds to the channel usage behaviour previously explained and is due to factors such as speed, convenience and flexibility of the digital channels. Despite the current level of development, it must be ensured, however, that senior citizens receive services of equal quality and price, even when visiting a branch. However, the majority of customers do not accept telephone banking. Here the clear majority (77.66\%) never uses the telephone option. Nevertheless, right now, many banks are expanding this contact option, which the customer experiences as rather cumbersome and slow. This means that the customers' actual account managers are often no longer directly accessible to them and the customers are forwarded to an internal or external call centre. From the bank's perspective, this may offer some advantages, but clients are not always adequately involved in this restructuring. For example, several banks have completely failed to inform customers that instead of their advisors, they will only be able to reach a call centre, which has led to great annoyance among customers. Another study by BAIN \& Company shows that no other channel is rated as badly as the call centre (BAIN \& Company 2016), and its acceptance has decreased even further in recent years (Oberle et al. 2016, 27). Therefore, the current expansion of telephone banking is seen critically. Especially since many banks expect their own call centre to become their largest branch for handling their whole retail business within the next few years.

In order to consider to what extent the integrated customer advisory service covers the customers' needs for basic products, customers were asked which products they currently use (see Figure 2). It turns out that customers are well supplied with current accounts. When it comes to savings, however, things look different. For example, 33.90\% of the customers surveyed do not have a savings account and $57.56 \%$ do not have a night money account. This shows that the holistic approach of advice already fails because many customers are not sufficiently supplied with basic banking products. The low level of interest in these accounts can be attributed, among other things, to the current low interest rates. However, for example, $38.61 \%$ of 26 to 45 year old customers do not have a savings account. At this age, however, financial buffers in the form of savings should be built up. This is seen critically esp. due to the increasing need for private pension provision. The lack of savings products could be balanced by fund savings plans, but only one third of the customers surveyed used any type of securities at all. 
This is partly because customers in Germany are rather sceptical about securitiy transactions (Godenrath 2013, 5). The proportion of customers who have neither a savings account nor hold securities and therefore cannot build up cash reserves outside of their current account or overnight deposit account is $24.84 \%$. The banks are therefore giving away a great deal of earnings potential in the current situation when it comes to securities, especially in the area of fund savings plans. For example, mainly younger customers are mostly willing to go to a bank branch for advice due to their lack of specialist knowledge about securities (Danesh-Kajouri 2018). In addition to classic fund savings plans, digital investment assistants (socalled robo advisors) could also be presented to them. The credit card, which is often the prerequisite for online transactions, is currently not used by $37.98 \%$ of customers. Aside from a lack of customer demand, this may be because many banks do not actively offer credit cards. If creditworthiness concerns are the reason for not offering them, the option of a prepaid card or only a small limit should be considered. However, here too, many banks are rather hesitant. It can therefore be stated that the holistic approach does not seem to be able to meet the basic needs of the customers and that banks leave a lot of opportunities unused. $55.19 \%$ of the customers surveyed cannot even remember their last consultation appointment.

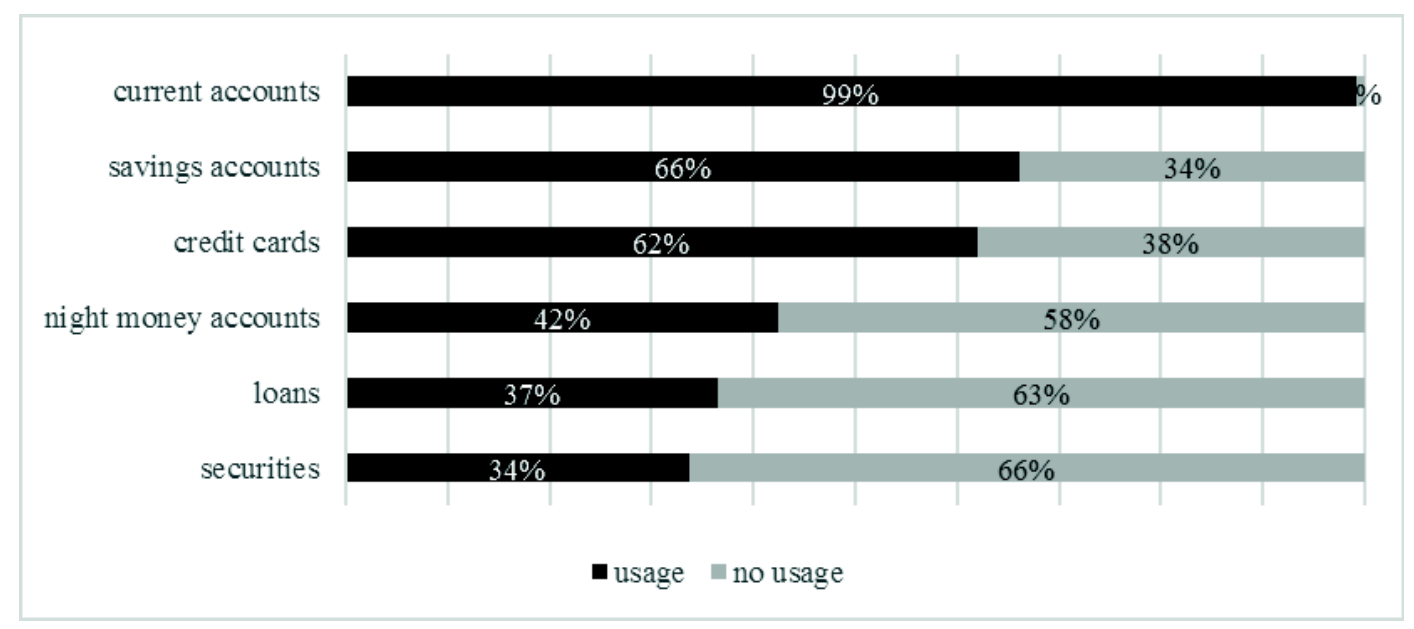

Figure 2. Usage of bank products

About one third of customers do not feel that they receive individual or needsbased advice (33.64\% and 32.19\%). Only 32.85\% and $42.49 \%$ of them feel that they are advised individually or according to their needs. The advisory skills are therefore no longer automatically assigned to banks (Mihm 2014, B7). Tests based on trial customers also show that the consultations are often insufficient (Fürderer $2016,228)$. The main deficits lie in the type of advice, since many employees no longer act holistically, but aim to sell certain products for which specific goals exist. 
What do German bank customers want? The importance of customer expectations...

\subsection{Communication, accessibility and pricing}

In addition to advice, customer communication and pricing play an important role in the customer experience (Quadient 2017, 3). For this reason, the current experiences of bank customers with regard to the communication, accessibility and pricing of the banks are examined.

In connection with the bank's current communication behaviour, customers were initially asked how often they are currently contacted by their bank. The vast majority of them $(73.35 \%)$ state that no telephone contact by the bank had been made. The majority of the remaining customers receive a call from their bank once a year (15.52\%). E-mail contact is also rare. Here, $67.33 \%$ of customers say that they do not receive emails from their bank. Otherwise, contact is made via email on average every six months. The most used communication medium is the letter. Only $23.86 \%$ of customers are not receiving letters from their bank. The frequency of establishing contact is significantly higher with this medium, since sales mailings are usually sent every four to six months. It should be emphasized that there is only a small number of customers who are currently not addressed by phone, email or letter (9.46\%). Thus, most customers have some sort of regular contact with their bank. According to the customers surveyed, the content is mostly campaign-driven advertising and rarely an invitation to consultations.

It can be observed that the majority of customers are fundamentally critical of every form of contact by their bank (see Figure 3).

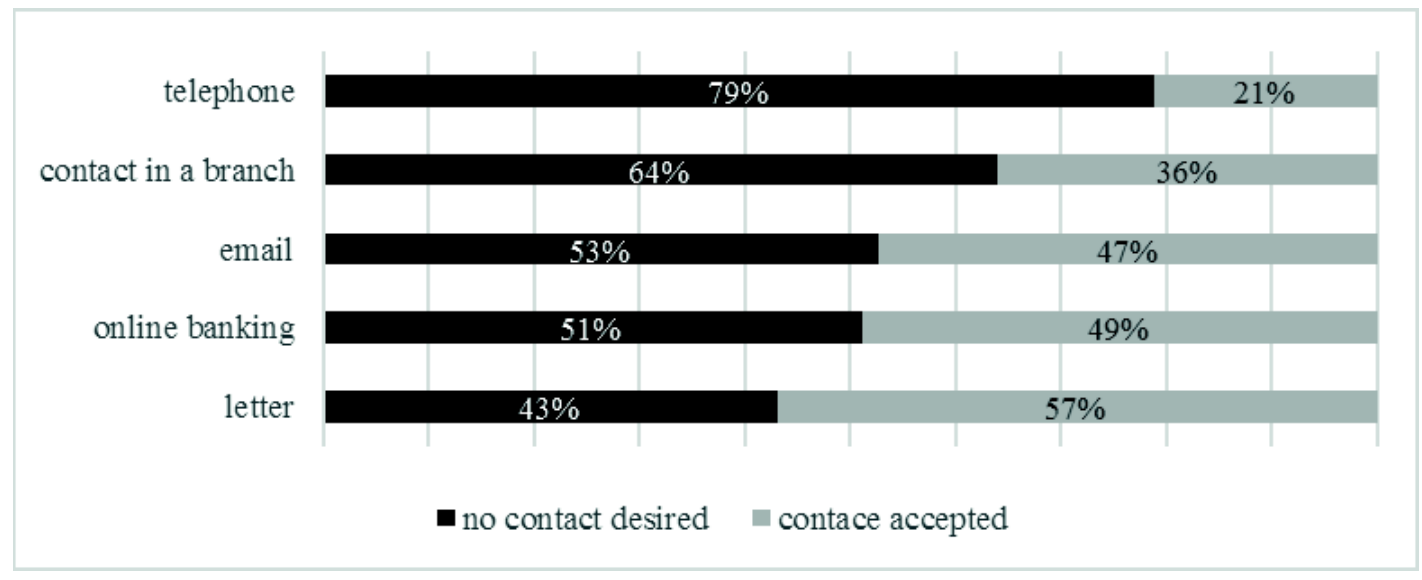

Figure 3. Customer requests regarding contact

The majority of customers (66.29\%) who had not been contacted via telephone describe this as reasonable. $78.84 \%$ of the bank customers surveyed agree that no telephone contact is desired. The perceived inappropriateness therefore increases above all if the bank has called the customer more than once in six 
months. Banks can therefore be advised not to contact customers by telephone on their initiative, as this is perceived as annoying and inappropriate. Younger working people in particular do not want to be contacted by phone at all (Mihm 2019, 14). Apart from being contacted via telephone, personal contact in the branch is least desired by customers. Just over half of the customers do not want to be contacted by email either. If contact is made via this medium more than once a year, the perceived inappropriateness also increases. Contact via online banking is rather accepted by customers. Even though $43.10 \%$ of customers still refuse to be contacted by letter, this is the most accepted way of being contacted. A half-yearly or annual contact is most accepted among the bank customers surveyed. It turns out that customers prefer the contact forms that are least binding for them. While telephone calls and direct conversations in a branch require personal interaction, e-mails and messages in online banking can be deleted and advertising letters - usually after a brief glance - can be disposed of easily. They therefore do not require any further action from the customer. Thus, it is not surprising that the option of communication most preferred by the surveyed customers is only a half-yearly letter without further efforts by the bank on other channels. The current contact by banks, which focuses on postal communication, is generally rated as appropriate. However, it is questionable whether the bank's attempts to contact their customers leave a lasting positive impression on them.

The option 'no contact on the initiative of the bank' appears to be most adequate for the majority of customers. Ultimately, an active approach is only justified if it is in line with the customers' needs (Boden 2016, 250). For this reason, the banks have to move away from their classical campaign thinking with widely distributed mailings (Jentsch 2016, 370; Wittkowski 2019, 2). In this context, the smartphone offers great potential for generating customer contact points, because customers use it countless times a day (Deloitte 2019). 69\% of bank customers in Germany already use a banking app (Bitkom 2019), which makes it possible to address and integrate information, products or services relevant to customers in a targeted manner.

While the customers surveyed sometimes feel disturbed by their bank's attempts to contact them, it is still important for them to be able to approach the bank themselves if they have major concerns. Therefore, the three biggest customer requests regarding contact options are:

- good availability of the banking consultant,

- a chat function in online banking,

- a call centre available $24 / 7$.

Customers only accept the communication via telephone, if they have an urgent request that requires immediate attention. The wishes expressed correspond 
What do German bank customers want? The importance of customer expectations...

to the expectations of customers for a convenient availability of the bank's range of services and products. With regard to the relative acceptance of digital channels, there is great potential for banks to optimize costs.

In addition, half of bank customers (50.72\%) have experienced changes in the accessibility of their banks in the past two years. These include:

- branch closures,

- shortened opening times,

- change of banking advisors.

$62.55 \%$ of customers are annoyed that their bank is less accessible for them. Here, banks have apparently not been able to compensate for the closure of branches through alternative contact channels. Meanwhile, only $25.36 \%$ of bank customers agree that the bank has managed to include them well in the changes that have been made, which shows that the banks have not considered customer requirements about the restructuring in advance, al-though the customers ultimately decide on the future existence of a bank. Therefore, customers were asked in this study what they want from their banks in general (see Figure 4).

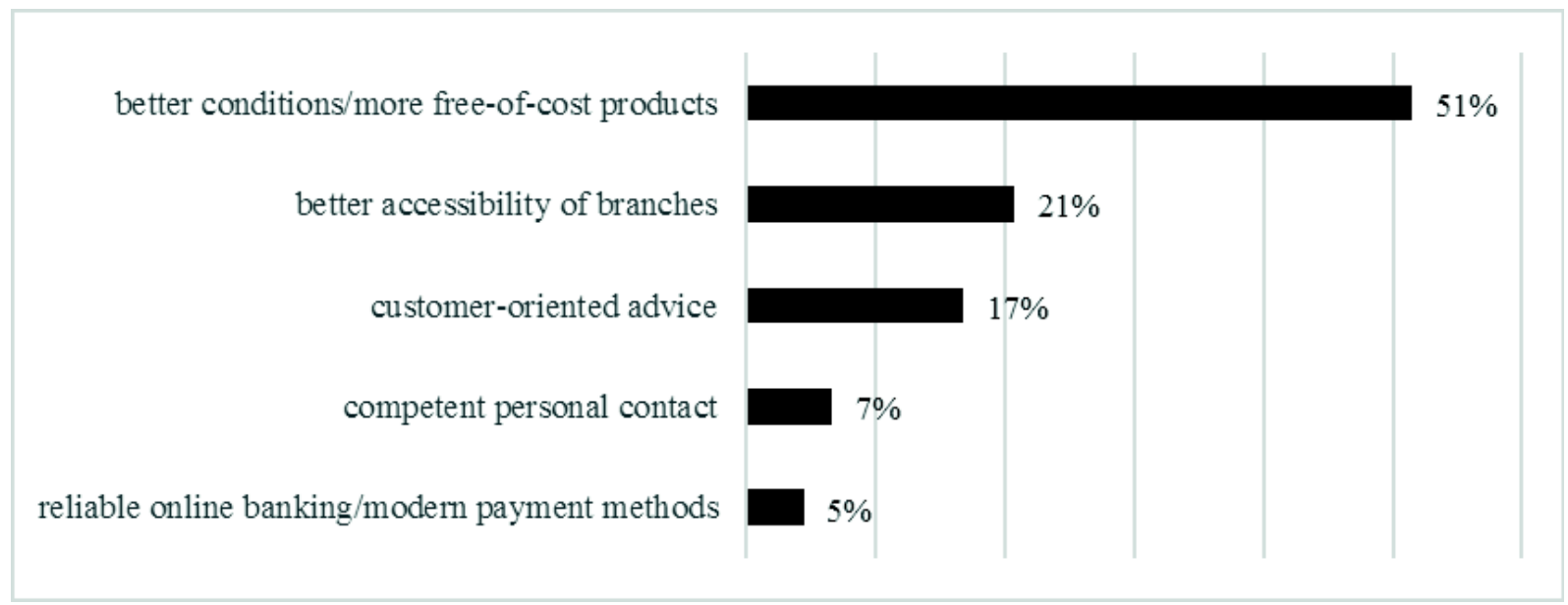

Figure 4. Customers' expectations

The most urgent issue for customers with regard to their bank is the current conditions. Most customers want better conditions and/or more free-of-cost options, which illustrates the customers' strong focus on price. In this context, $56.11 \%$ of the customers surveyed agree that their bank offers them a lower service but still increases its prices. This is not in line with the explained customer requirement for excellent service quality at the best price. In addition, almost half of the customers $(47.70 \%)$ do not understand why they now have to pay fees for 
services that were previously free of charge. There is a high displeasure that the increased fees go hand in hand with lower or no interest. Price perception plays an outstanding role for emotional components of business relationships, such as perceived fairness for customers (Frank, Mihm 2018, 14). Instead of improving the price-performance ratio that customers perceive as negative, banks continue to increase their account fees due to the ongoing low interest rate phase and react with non-transparent accounts and hidden fees (Schleidt 2019), which does not match the customers' expectations for transparency. For example, around 50 banks in Germany are already charging a penalty interest rate from private customers (Witte 2019). Some of them even charge a penalty interest rate of $0.5 \%$ on the customer's credit card balance from the very first Euro. Furthermore, the majority of banks are considering getting rid of free accounts and introducing additional fees. At the moment, there seems to be no limit to the introduction of new fees. A current example of this is the time-dependent fees for withdrawing money from ATMs (n.u. 2019e), which means that customers have to pay a fee for every transaction made outside normal business hours. Customers usually do not feel adequately informed about the additional fees. In addition, two thirds of banks in Germany already charge withdrawal fees, which makes disgruntled customers susceptible to competitive offers. The customers do not understand why they should pay to get their own money. Overall, one third of German banks increased their prices in the last two years or charged fees for services that were previously free of charge - on average by up to 30\% for online, basic and classic branch accounts and up to $20 \%$ for premium accounts (Böhmert 2019a, 2). Due to the mainly negative assessment of the previous price-performance ratio of traditional banks, this development will not contribute to increasing customer satisfaction and can therefore lead to a significant customer loss. Banks should consider this, as they cannot rely forever on the convenience of bank customers that prevents them from cancelling their relationship to a bank.

Other wishes expressed by the customers are a better accessibility of the consultants on site, coupled with customer-oriented advice. In line with the idea of convenience, customers want a secure and reliable online banking and access to modern payment methods. However, the comparatively low mention of the latter points must not lead to the conclusion that those aspects are not important to customers. For customers, aspects such as:

- good advice,

- convenience,

- the possibility of online banking,

- personal contact

are of great importance (see Figure 5). 
What do German bank customers want? The importance of customer expectations...

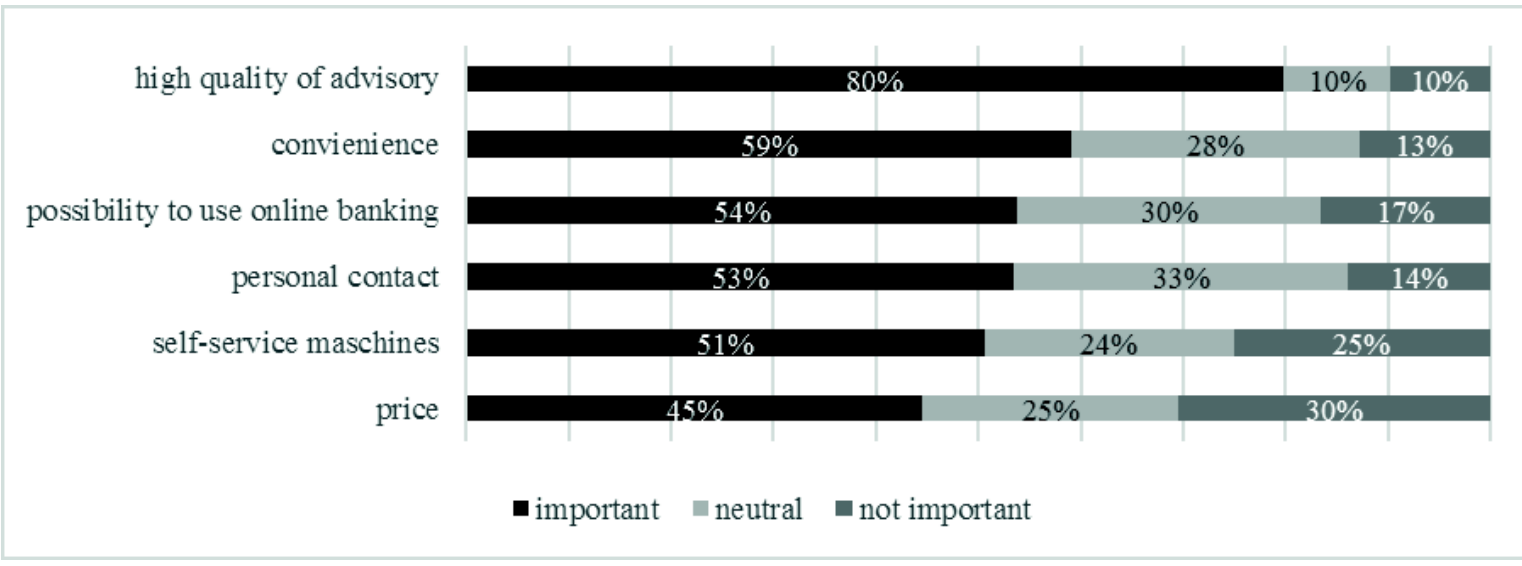

Figure 5. Important aspects for customers when doing their banking

The results clearly show that ensuring good advice is the most important aspect as $79.76 \%$ of those surveyed stated that high-quality advice is important to them. This highlights the outstanding importance that the quality of advice still has today. The study results continue to emphasize the importance of convenience for customers. Online banking is an important consideration for $53.75 \%$ of customers. This illustrates the high relevance of digital channels. With $53.48 \%$ personal contact is almost as important to customers. The price is mentioned by $45 \%$ of the customers as an important factor, which in turn underlines the customer's request to the best service at the lowest price and the demand for better conditions.

The customers surveyed here did not mention the individual aspects of online banking. It can be concluded from this that the banks already meet customer expectations in this area. In view of the high quality standards that customers expect from their bank these days, employee qualifications must be borne in mind by banks in order to guarantee high-quality customer care.

\subsection{Customer orientation of banks}

For the future competitiveness of banks, it is essential to understand their customers' concerns and needs (Neubacher 2019a, 2), since customer-oriented behaviour has a lasting positive effect on customer satisfaction (Homburg, Bucerius $2016,80)$. For this reason, customers were asked about their perception of their bank's customer orientation (see Figure 6).

Almost half of the customers surveyed do not believe that their bank even knows what they want in financial matters. It can be concluded from this that banks do not seem to ask their customers about current wishes on appropriate occasions, even though this is the basis of any good and holistic advice. However, 
even if the customers' wishes are known, only $42.05 \%$ of bank customers feel that the banks cater specifically to those wishes. This means that products are currently not fulfilling these explicitly expressed wishes. Instead, within the consultation, an attempt is made to sell products to the customer that are not in line with their wishes. $37.98 \%$ of customers currently feel that their bank only offers those products to them that the bank makes good money with. It is therefore not surprising that the majority of customers (56.90\%) gets the impression that banks are not interested in their wishes. Thus, it is assumed that the interests of a bank are often put ahead of those of their customers. Exactly half of the customers surveyed also have the impression that banks cannot assess what their customers need in financial matters. This shows that no targeted product recommendation is currently being given. It can therefore be summed up that customer relationships today are particularly at risk of a lack of customer orientation (Mihm, Wollmann 2018, 7-8). Due to the behaviour of the banks, more than half of the customers no longer feel respected and valued by their bank (Kuhn 2015, B8). In view of the fact that banking products are interchangeable from the customer's point of view, and that support and advisory services are the most important differentiating feature from the growing competition (Kuhn 2016, B6), these results should encourage banks to change their current behaviour.

My bank knows what I need in financial matters.

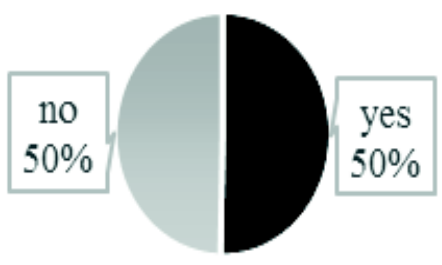

My bank knows what I want in financial matters.

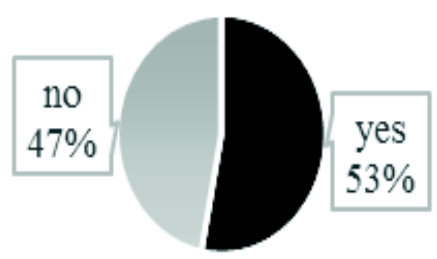

My bank is interested in my wishes in financial matters.

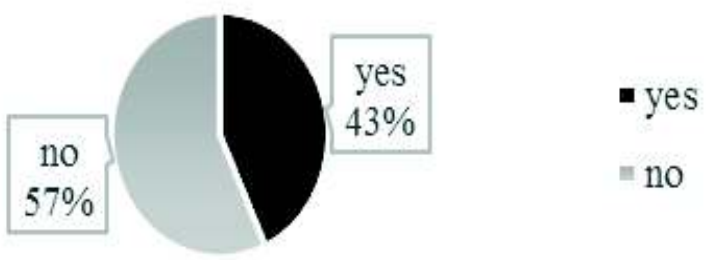

My bank caters to my wishes in financial matters.
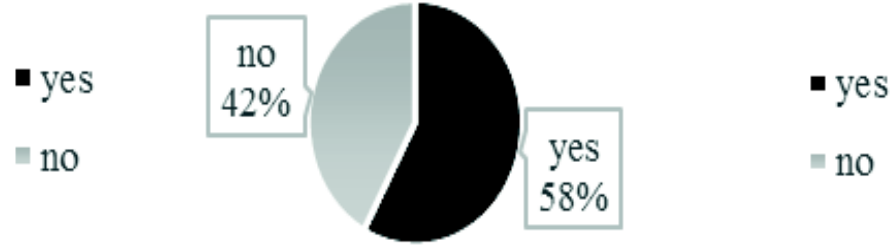

Figure 6. Perceived customer orientation of banks 
What do German bank customers want? The importance of customer expectations...

\section{Recommendations for banks}

\subsection{Expand the omni-channel approach}

Customers expect a banking service that can be integrated into their networked everyday life at any time (Capgemini, Efma 2018, 7). For example, banks now have to offer more than the simple digitization of what was previously available (Fischer 2019b, 3). Almost half of the customers criticize that German banks are far behind in their digital offer compared to international banks (Streim et al. 2019). Today's bank customers no longer distinguish between the individual channels and intuitively select the channel that is most suitable for them in their current situation - expecting their data is available in the other channels as well. For this reason, all channels must interlink in an omni-channel approach (Waidelich 2015,2 ), because only the networking of all services to form an integrated advice enables the potential of all sales and communication channels to be fully exploited and the wishes of customers to be put first (Oberle et al. 2016, 5). The customers can be offered a high-quality service via every channel (Dölle 2017). Only banking services that become a completely closed customer experience across all channels generate enthusiasm and are proof of quality (Oberle et al. 2016, 8). Barriers, media breaks and waiting times need to be reduced (Neuhaus 2018, B7; Lieberknecht 2019a, 29), since these are only barely tolerated by customers (Lieberknecht 2019a, 29). Furthermore, customers must be able to purchase the majority of the products uncomplicatedly, digitally and promptly (Oberle et al. 2016, 12). This not only lowers the banks' sales and processing costs, but also leads to greater customer satisfaction. The necessary standardization and automation of the processes that would be necessary for full integration into omni-channel management leaves much to be desired due to the required manual processing steps, outdated structures and missing inter-faces in many banks (Godenrath 2016, 5). Banks miss the fact that the simplification of pro-ducts, processes and structures also goes hand in hand with increased efficiency in the medium to long term (Bergmann, Vater 2015, 3). Mobile banking is increasingly in demand, which means that it has to be as value adding as the website and the branch (Vishnoi 2019). It enables banking to be integrated much more closely into the customer's everyday life (Oberle et al. 2016, 14). The proportion of internet-orientated customers will increase continuously in the future due to demographic change (Hellenkamp $2016,384)$, thus, the general need for branches will continue to decrease in the future (Vogelgesang 2015, 711). Due to the change in customer behaviour, small processing branches that do not provide advice (Stoltenberg 2017, 4) are more likely to be affected by this development than large consulting branches at central locations. For this reason, in the future, only branches offering a wide range of 
services will add value (Godenrath 2017,5 ). The justification for the existence of service-free micro-branches, whose services are primarily digitally performed today, must therefore be critically examined in terms of cost-effectiveness (Barkey 2019, 973), because customers often see no added value here. Investments in digitization and branch redesign have been shown to increase customer satisfaction (Deloitte 2018, 2, n.u. 2019h, 7). The majority of customers want innovative branch concepts with an appealing atmosphere like in an Apple Store or Starbucks (Berger et al. 2015, 16). One option that would make one third of customers visit the branch more often is a café-like design, where they can relax and work at the same time (Deloitte 2018, 17). Classic bank branches with an old structure and equipment will therefore have no chance of survival in the future (Erlebach, Kölbach 2016, 937). Customers will not accept unlovingly renovated branches without a fundamentally new character. The customers must therefore be actively involved in the restructuring, because in the end they decide whether the branch as a concept dies or whether it will continue to live in the future.

\subsection{Increase the quality of advice}

Currently, almost half of bank customers have a detailed consultation less than every two years, with the initiative mostly coming from the customers themselves (Terliesner 2019, 13). As a result, many customers do not feel well looked after by their bank. If advice that is truly needs-based is to be provided, it must be consistently geared to customer wishes and needs, instead of pursuing pure product sales in accordance with a bank's goals (Holböck 2006, 199). Therefore, one of the key elements lies within a bank's goal system (Färber, Hopfner $2006,41)$. If a bank is interested in high quality, demand-oriented holistic advice, it cannot focus its goals solely on single products and the earnings that can be achieved by selling them (Kuhn 2015, B8). Controlling and management based on individual goals and campaigns is unsuitable because the consultant mainly acts due to sales pressure (Scherber 2019). For this reason, the goal systems of many banks have to be thoroughly reconsidered. Potential-oriented goal planning, for example, makes sense, but has not yet been introduced in most banks due to its complexity. Furthermore, the development towards a networked and open omnichannel world makes classic control mechanisms increasingly unusable due to the difficult attribution of results (Rega 2019, B10). Thus, the impression arises that often only products are sold on which the banks earn a lot. For this reason, bank customers are currently increasingly distrusting of their banks (Buchholz 2018, B4; n.u. 2019f, 33).

Customer understanding is one of the central parameters of all success formulas (Duttenhöfer 2019; Rohrmeier 2019, B5). Banks and financial service 
What do German bank customers want? The importance of customer expectations...

providers have a comprehensive, mostly unused, database, which enables them to derive detailed customer profiles with an assessment of their personality and lifestyle (Gensch, Müller 2019, 262). Data evaluation using artificial intelligence can make a significant contribution to increasing sales efficiency, since it can be used to derive offers tailored to the customer. This data has a high economic value. Bank customers are also generally willing to share their data with the bank, but in return, they expect high-quality products and services, as they are increasingly aware of their data's value (Vishnoi 2019). The interaction can become a positive experience for the customer through the desired individualized approach (Mihm, Jacobs 2017, 13; Capgemini, Efma 2018, 46). In this regard banks can and should learn from large technology companies such as Google, Amazon, Facebook and Apple (Thole 2019, 270). However, the prere-quisite is high-quality customer data that has no inconsistencies (Quadient 2019, 2). It is therefore necessary to consolidate all available data that can be enriched by external sources (Sinn, Schmundt, 2017, 25). With these measures, the potential of previously inactive customers can also be activated (Terliesner 2019, 13 and 16).

Proximity to the customer has been one of the unique selling points of branch banks. In view of digitization, however, the definition of the term 'customer proximity' has to be revised (Kolak 2018). Personal consultations no longer necessarily require the presence of the consultant in the same room, but are also possible by using video communication (Kautz 2018, 4; Streim et al. 2019). Over one third of customers are already willing to accept video telephony as a consulting solution (Leichsenring 2017; n.u. 2019d, 4) because it meets their need for convenience, flexibility and speed (Berger et al. 2015, 15). In addition, the quality of advice can be further increased by simply including experts in real time. Holistic advice should consider the type of communication preferred by the customer (Oberle et al. 2016, 9). The goals of banking advisors include regular appointments with their customers. However, half of bank customers do not want this because it does not meet their actual need for advice (Oberle et al. 2016, 20). It is important for the customer to be looked after by the bank on the right occasions. This underlines the importance of evaluating existing customer data. Furthermore, the time period that customers allow for advice is very limited. The majority of customers only accept a time window of a maximum of 30 to 45 minutes, which often does not correspond to current practice (n.u. 2019d, 4).

The changed customer requirements thus have a significant impact on the banks' sales structures (Kleine, Jolmes 2019, 246). High-quality advice is associated with investments, but a lack of quality costs the trust of the customers and ultimately the customers themselves (Kuhn 2015, B8), since the willingness to switch banks when the expectations placed on the customer experience are not met, is very high (Quadient 2017, 6). It should be noted here that the majority 
of customers do not express their displeasure, so that possible tendencies to leave are only recognized when it is already too late (Vishnoi 2019). In general, leaving a bank is usually not planned by the customer, but rather the result of unused opportunities from their bank (Oberle et al. 2016, 4). For this reason, $50 \%$ of customers would switch banks for better advice (Meinl 2016, 4). Among other things, due to the existing cost pressure, efficient and value-adding advice for the survival of the banks is required (Oberle et al. 2016, 20).

\section{Critical conclusion}

In order to survive on the market and gain competitive advantages, banks must know and meet their customers' expectations and, in the best case, even exceed them (Weigl 2001, 59). This is crucial for the success of banks (Frank, Mihm 2018, 16). However, banks have been defensive for more than ten years due to the consequential damage caused by the financial and economic crisis. Therefore, the necessary change is particularly difficult in Germany (Neubacher 2019a, 2). While lamenting low interest rates and increasing regulatory requirements, they are wasting valuable time they could use to focus on a more profitable business model. Banks must stop reacting only to external influences, but start to act actively (Seidl 2017, 476; Vishnoi 2019). Due to the lack of customer orientation and the lack of emotional elements, banks are at risk from growing digital competition (Mihm, Wollmann 2018, 6).

The starting position for German banks is relatively good, as they have the closest contact with their customers when compared internationally. However, they are unable to use this advantage sufficiently (Fischer 2016, 2). Due to the poor coverage of the basic products and the customer assessment that banks do not respond to the wishes of their customers, if they show any interest at all, a failure of the current design of the customer relationship approach can be observed. Only one third of the customers surveyed currently feel that they have received individual advice. This is particularly critical, since the quality of advice is one of the very few differentiating features of classic branch banks (Boden 2016, 248; Kuhn 2016, B6; Becher 2017, 4). It is time for banks to align their customer relationship concept with actual customer needs. However, due to the currently counterproductive target design, they first have to realign their sales structure and management (Ronzal 2006, 216). The desire for needs-based advice cannot be fulfilled if individual product targets are set for the sales employees. Data evaluations can help to generate a comprehensive understanding of the customers and their needs and thus optimize customer care (Köllnberger et al. 2014, 2). Above all, the decreasing personal contact with customers can be compensated 
What do German bank customers want? The importance of customer expectations...

(Eck 2019, 301). Tailor-made solutions are crucial for the customer (Zeisl 2018, 47) as $87 \%$ of bank customers already agree that banking services should be personalized (Wenzel 2017).

The content of any advertising measures must therefore be up-to-date, meaningful and relevant to the customer and not be part of obvious cross- or upselling efforts (Bellens 2016). Currently, fewer than one third of customers believe that banks recommend products that are relevant to them (Capgemini, Efma 2019, 12). The previous communication behaviour therefore does not provide any real benefit for the customer (Serra 2018). This is also reflected in the previously mentioned study results. In the current form, the customers preferably do not want their banks to contact them. However, a well-directed addressing of customer requests can increase customer satisfaction and loyalty, which ultimately has a positive effect on the economic success of a bank (Köllnberger et al. 2014, 2). In this regard, it is crucial to explicitly ask the customer about their wishes in a personal conversation and to address exactly those wishes, instead of primarily selling products that the customers do not want and do not need.

It is therefore not surprising that German customers are currently unsatisfied with their banks when compared internationally (Deloitte 2018, 5). This is also underlined by this study. It shows that many of the basic customer expectations are not met at all but also, above all, that the current price-performance ratio is viewed critically. In the future, however, simply meeting expectations will no longer be enough to satisfy customers (Protiviti 2016, 20). Only one third of customers state that the respective bank has actually managed to delight them by exceeding their expectations (Protiviti 2016, 4). Therefore, there is a huge gap between the current expectations of customers and the actual offers and behaviour of banks (Wenzel 2017; Schimpf 2018). Not even half of the top decision-makers within the banks themselves believe that their services meet the needs of customers (n.u. $2019 \mathrm{c}, 6)$. The increasing willingness of customers to switch to another bank is primarily due to their general dissatisfaction (Erle 2016). In this context, it is not surprising that only one third of customers describe themselves as tied to their bank - and numbers are degreasing (Gallup 2019). Classic banks are therefore becoming less and less relevant (Bellens 2016).

By not directly meeting the changed expectations, customers no longer experience a benefit from the banking relationship, which makes them susceptible to competitive offers (Mihm 2019, 14; Werne 2019, 28). A recent study shows that about half of the customers consider banks and financial institutions to be interchangeable (YouGov 2019, 2). The focus on customer experience that technology companies and fintechs offer is not a competence of traditional banks (Galla 2019). It is therefore not surprising that a large number of customers is willing to try financial products from the large technology companies such as Google, 
Apple, Facebook and Amazon (Böhmert 2019b, 3; Rohrmeier 2019, B5, Streim et al. 2019). In order to achieve genuine and voluntary customer loyalty, the customers need to develop an emotional connection to their bank (Hanreich 2006, 211). Therefore, it should be worrying for traditional banks that many customers already have a stronger emotional bond with these technology companies than with them (Deloitte 2018, 6). The technology companies offer services that are transparent, delight the customer and, thus, offer a real benefit for them (Deloitte $2018,6)$. Thus, they offer products that are superior from the customer's perspective (Capgemini, Efma 2019, 14). The actual differences are not important (Inhoffen 2019). What is important when differentiating is only the difference perceived by the customer. Not only customers, but also dedicated, well-trained specialists who are essential for the continued existence of banks are currently more attracted to technology companies (Brüggestrat, Ohlsen 2019, 1050). Moreover, the pressure to act is increasing, since Google has announced its own current account in collaboration with Citigroup in addition to their existing payment service Google Pay (Leichsenring 2019a; Rudegeair, Hoffmann 2019; Simmank 2019). Apple not only offers the payment service Apple Pay, but also its own credit cards. Facebook introduced a new payment service that should be applicable in all of the group's apps. Amazon is also expected to launch a current account. The banking and financial services offer technology companies the opportunity to bind their customers even closer. This primarily involves obtaining valuable financial data in order to further expand customer knowledge (Leichsenring 2019a). Due to the increasing competition, banks are already facing billions in losses.

The world is moving faster than ever, and this requires a corresponding ability to adapt (Werne 2019, 28). Banks must finally get out of their comfort zone and face the challenges ahead (Serra 2018). Meanwhile, fintechs do not have to be viewed as opponents, but as a source of inspiration (Oberle et al. 2016, 8). Both sides will benefit from strategic alliances and collaborations (Brunke 2019, 110-111; Gensch, Müller 2019, 267; Grigo 2019, 21; Murray 2019, 355; Popp 2019). They can help break up the established thinking and behaviour of banks (Oberle et al. 2016, 8). In addition, opening oneself up to financial platforms can add value and knowledge (Neubacher 2019b, 2). Investments in digitization and branch redesign have been shown to increase customer satisfaction among bank customers (n.u. 2019h, 7). It is important to intensify the customer relationship with the help of intelligent virtual assistants such as chat bots, which can be integrated, for example, in a messenger (Crealogix 2018, 11). In the banking sector in particular, the demand for messenger communication has increased significantly (n.u. 2019g, 6). The use of live chats is currently becoming more important (Vishnoi 2019). Here, competent digital advice can strengthen customer trust. Voice control via assistants such as Alexa can represent a new communication 
What do German bank customers want? The importance of customer expectations...

channel (Schneider 2019, 34). Additional services such as travel insurance can also increase the attractiveness of individual products (n.u. 2019b,).

Banks are more known for sticking to the tried and tested. However, due to the current challenges, they have no option but to strengthen their innovative capacity (Ili, Lichtenthaler 2017, 21 and 35). Ultimately, the digital transformation - despite all cost pressures - is not an option, but is essential for survival (Stollarz 2018, B5) in order to meet future customer requirements. Ensuring high quality customer service and expanding omni-channel management are the keys to customer loyalty (Vishnoi 2019). Only those banks who consistently put the customer in the centre and enable them to enjoy an outstanding, holistic experience across all channels will be able to retain their customers in the end (Crealogix 2018, 5). With this strategy, the branch as a communication channel can also be upgraded (Vogelgesang 2015, 712). In the meantime, branches need to change in order to survive in the future (Weißer, Zdrzalek 2016, 216). They must be customer-oriented, competent, strong in contact and interactive, and create an emotional benefit for their customers. They also have to offer services that have not yet existed in this form on digital channels (Erlebach, Kölbach 2016, 937). Banks must manage to become an integral part of customers' lives (Serra 2018). If not, they will end up as primary care providers who only provide standard services while new providers occupy the high-margin products (Bergmann, Vater 2017). However, if traditional banks manage to offer comparable offers at similar conditions as their competitors, more than half of the customers who had left would be willing to return (Fischer 2019a, 3). Customers are clearly expressing their expectations - it is finally time for the banks to listen.

\section{References}

[1] Accenture (2016) 2016 North America Consumer Digital Banking Survey: Banking on Value - Rewards, Robo-Advice and Relevance, [Online], Available: https://www.accenture.com/t20160609T222453_w_/us-en/_acnmedia/ PDF-22/Accenture-2016-North-America-Consumer-Digital-Banking-Survey. pdf [3 Jan 2020].

[2] Accenture (2018) Anforderungen an Banken bei der Kundenbindung und -gewinnung im Jahr 2010 (aus der Sicht der CEOs von Retailbanken), [Online], Available: https:/de.statista.com/statistik/daten/studie/166632/umfrage/anforderungen-an-banken-bei-der-kundenbindung-und--gewinnung/ [3 Jan 2020].

[3] Actico (2019) Automatisierung von Kreditentscheidungen: Kosten senken und Effizienz steigern, [Online], Available: https://www1.actico.com/hubfs/ Content/Whitepaper/kreditentscheidungen-automatisieren-whitepaper-actico-de.pdf [3 Jan 2020]. 
[4] Aldred, M. (2019) Welche Trends für das Bankwesen 2019 wichtig werden, [Online], Available: http://www.av-finance.com/aktuelles/newsdetails/seite/10/artikel/162/welche-trends-fuer-das-bankwesen-2019-wichtig-werden/ [3 Jan 2020].

[5] Anderson, E.W., Fornell, C. and Lehmann, D.R. (1994) 'Customer Satisfaction, Market Share, and Profitability: Findings from Sweden', Journal of Marketing, vol. 3, pp. 5366.

[6] Andrae, S., Hellmich, M. and Schmaltz, C. (2018) Bankenaufsichtliches Risikomanagement: Grundlagen und Anwendung regulatorischer Anforderungen, Stuttgart: Schäffer-Poeschel.

[7] Bain \& Company (2016) Drehscheibe der Retail-Bank der Zukunft, [Online], Available: https://www.bain.com/de/ueber-uns/presse/pressemitteilungen/ germany/2016/drehscheibe-der-retail-bank-der-zukunft/ [3 Jan 2020].

[8] BaFin (2019) Ergebnisse des LSI-Stresstests 2019, Pressemitteilung vom 23.09.2019, [Online], Available: https:/www.bafin.de/SharedDocs/Veroeffentlichungen/DE/Pressemitteilung/2019/pm_190923_lsi-stresstest.html [3 Jan 2020].

[9] Bankenverband (2018) Online-Banking in Deutschland: Repräsentative Umfrage im Auftrag des Bundesverbands deutscher Banken, [Online], Available: https://bankenverband.de/media/files/2018_06_19_Charts_OLB-final.pdf [3 Jan 2020].

[10] Barkey, R.W. (2019) 'Kundenberatung 2030 zwischen Empathie und Künstlicher Intelligenz', $Z f g K$, vol. 19, pp. 972-975.

[11] Bartels, G. and Djouimai, J. (2005) 'Eckpfeiler langfristiger Kundenbindung', in Effert, D. and Ronzal, W. (ed.) Erfolgreiche Vertriebsstrategien in Banken: Von den Besten profitieren, Wiesbaden: Springer Gabler.

[12] Becher, W. (2017) 'Ist das Firmenkundengeschäft bald in der Demografiefalle?', Börsen-Zeitung, vol. 95, p. 4.

[13] Bellens, J. (2016) How retail banks must rethink their customer relationships, [Online], Available: https://www.ey.com/en_gl/banking-capital-markets/ how-retail-banks-must-rethink-their-customer-relationships [3 Jan 2020].

[14] Berger, R. et al. (2015) Digitale Revolution im Retail-Banking - Chancen in der neuen Multikanal-Welt aus Kundensicht, [Online], Available: https://www. rolandberger.com/de/Publications/Digitale-Revolution-im-Retail-Banking.html [3 Jan 2020].

[15] Bergmann, M. and Vater, D (2015) Loyalität im Privatkundengeschäft - Erfolgsmodell Omnikanal, [Online], Available: https://www.bain.com/conten tassets/8b4df63f4ba341dadff2e5ba58bff9d/bain-studie_kundenloyalitc3a4t20im20privatkundengeschc3a4ft_final.pdf [3 Jan 2020].

[16] Bergmann, M. and Vater, D. (2017) Omnikanal kommt oder der Kunde geht: Überzeugende Omnikanal-Konzepte für die Hausbank, [Online], Available: https:/www.der-bank-blog.de/omnikanal-kommt-oder-der-kunde-geht/strategie/29936/ [3 Jan 2020]. 
What do German bank customers want? The importance of customer expectations...

[17] Bitkom (2019) Umfrage zur Nutzung von Banking-Apps in Deutschland 2019, [Online], Available: https:/de.statista.com/statistik/daten/studie/900222/umfrage/nutzung-von-banking-apps-in-deutschland/ [3 Jan 2020].

[18] Bocken, R. and Hagedorn, J. (2018) 'Private Baufinanzierung: Digitalisierung als strategische Lösung', Die Bank, vol. 06, pp. 54-59.

[19] Boden, L. (2016) 'Bedarfsorientierte Beratung versus aktiver Bankvertrieb: Ein Widerspruch?', in Hellenkamp, F. (ed.) Handbuch Bankvertrieb: Theorie und Praxis im Zukunftsdialog, Wiesbaden: Springer Gabler.

[20] Böhmert, K. (2019a) 'Banking wird teurer', Börsen-Zeitung, vol. 193, p. 2.

[21] Böhmert, K. (2019b) 'Der Bankkunde wird digitaler: Volks- und Raiffeisenbanken starten Instant Payment', Börsen-Zeitung, vol. 97, p. 3.

[22] Brüggestrat, R. and Ohlsen, A. (2019) 'Mit stabilen Mitarbeitern dem digitalen Wandel begegnen', $Z f g K$, vol. 20, pp. 1050-1052.

[23] Bruhn, M. (2012) Marketing für Nonprofit-Organisationen: Grundlagen, Konzepte, Instrumente, Stuttgart: Kohlhammer.

[24] Bruhn, M. (2016) Qualitätsmanagement für Dienstleistungen: Handbuch für ein erfolgreiches Qualitätsmanagement, 10th edition, Wiesbaden: Springer Gabler.

[25] Buchholz, L. (2018) 'Kunden sollten über ihren Schutz selbst entscheiden: Pauschales Misstrauen überschattet Beziehung zum Bankberater', BörsenZeitung, vol. 196, p. B4.

[26] Büschgen, H. and Büschgen, A. (2002) Bankmarketing, 2nd edition, Düsseldorf: Verlag Wirtschaft und Finanzen.

[27] Brackert, T. et al. (2019) Global Retail Banking 2019 - The Race for Relevance and Scale, [Online], Available: http://image-src.bcg.com/Images/BCG-TheRace-for-Relevance-and-Scale-Oct-2019_tcm108-232288.pdf [3 Jan 2020].

[28] Brock, H. (2015) 'Vom Mono- zum Multichannel-Management: Nur wer die Vergangenheit kennt, kann die Zukunft erfolgreich gestalten', in: Brock, $H$. and Bieberstein, I. (ed.) Multi- und Omnichannel-Management in Banken und Sparkassen: Wege in eine erfolgreiche Zukunft, Wiesbaden: Springer Gabler.

[29] Brunke, S. (2019) 'Banken und Fintechs: Partner für die Zukunft', Finanz Colloquium Heidelberg, vol. 07+08, pp. 110-115.

[30] Capgemini and Efma (2018) World Retail Banking Report 2018, [Online], Available: https://worldretailbankingreport.com/resources/world-retail-banking-report/ [3 Jan 2020].

[31] Capgemini and Efma (2019) World Retail Banking Report 2019, [Online], Available: https://worldretailbankingreport.com/resources/world-retail-banking-report-2019/ [3 Jan 2020].

[32] Crealogix (2018) The Future of Banking - Die vielfältigen Chancen der digitalen Evolution, [Online], Available: https://cdn2.hubspot.net/hubfs/3216137/ WW/Future\%20of\%20Banking/CREALOGIX_Whitepaper_FutureofBanking_ ch.pdf [3 Jan 2020]. 
[33] Danesh-Kajouri, M. (2018) Future of Banking - Gleichung mit vielen Unbekannten - Banken müssen heterogene Kundenerwartungen erfüllen, [Online], Available: https://www.der-bank-blog.de/future-banking-kundenerwartung/digital-banking/32147/ [3 Jan 2020].

[34] Daum, W. and Degel, J. (2005) 'Kundenbindung: «must have» oder Modeerscheinung?' in Effert, D. and Ronzal, W. (ed.) Erfolgreiche Vertriebsstrategien in Banken: Von den Besten profitieren, Wiesbaden: Springer Gabler.

[35] Deloitte (2018) Accelerating digital transformation in banking - Findings from the global consumer survey on digital banking, [Online], Available: https://www2.deloitte.com/content/dam/Deloitte/us/Documents/financialservices/us-accelerating-digital-transformation-in-banking.pdf [3 Jan 2020].

[36] Deloitte (2019) Wie häufig schauen Sie pro Tag auf Ihr Smartphone?, [Online], Available: https:/de.statista.com/statistik/daten/studie/744138/umfrage/ umfrage-zur-taeglichen-nutzungshaeufigkeit-von-smartphones-in-deutschland/ [3 Jan 2020].

[37] Deutsche Bundesbank (2019) Monatsbericht September 2019, [Online], Available: https://www.bundesbank.de/resource/blob/807246/81c4d8a4375 fa08eb2cffa $406720445 \mathrm{~d} / \mathrm{mL} / 2019-09-$ monatsbericht-data.pdf [3 Jan 2020].

[38] Dittrich, S. (2002) Kundenbindung als Kernaufgabe im Marketing: Kundenpotentiale langfristig ausschöpfen, St. Gallen: Verlag Thexis.

[39] Dölle, A. (2017) Kundenbindung bei Banken durch digitale Services: Andreas Banger, Vorstand Volksbank Gronau-Ahaus, im Interview, [Online], Available: https:/www.d-velop.de/blog/branchenprozesse/kundenbindung-bei-bankendurch-digitale-services/ [3 Jan 2020].

[40] Duttenhöfer, S. (2019) Brauchen Kunden noch Banken?: Neobanken besetzen die Kundenschnittstelle mit bedürfnisgetriebenen Konzepten, [Online], Available: https://www.der-bank-blog.de/brauchen-kunden-banken/digitalbanking/37657087/ [3 Jan 2020].

[41] Eck, W.A. (2019) 'Big Data in der Finanzbranche: Vom Geldverwalter zum Daten-Magnat', FLF, vol. 06, pp. 300-303.

[42] Erle, C. (2016) Die Säulen der Kundenbindung: Diese 3 Dinge wollen Verbraucher von Banken, [Online], Available: https://www.management-circle. de/blog/kundenbindung-verbraucher-banken/ [3 Jan 2020].

[43] Erlebach, P. and Kölbach, R. (2016) 'Die Filiale der Zukunft: die Zukunft der Filiale', $Z f g K$, vol. 19, pp. 936-939.

[44] Färber, B. and Hopfner, W. (2006) 'Vertriebsintensivierung: Privatkundenstrategie 2012', in Effert, D. and Hanreich, W. (ed.) Ganzheitliche Beratung bei Banken: Modeerscheinung oder Erfolgskonzept, Wiesbaden: Springer Gabler.

[45] Finn, A. (2005) 'Reassessing the Foundations of Customer Delight', Journal of Service Research, vol. 02, pp. 103-116.

[46] Fischer, T. (2016) 'Vertrauensschwund hemmt Banken: Starke Kundenbindung gerät auch durch Fintechs in Gefahr', Börsen-Zeitung, vol. 97, p. 2. 
What do German bank customers want? The importance of customer expectations...

[47] Fischer, T. (2018) 'Privatbanken könnten jede zweite Filiale abbauen: Viele Zweigstellen nicht mehr wirtschaftlich', Börsen-Zeitung, vol. 243, p. 3.

[48] Fischer, T. (2019a) 'Banken können auf Rückkehr von Neobank-Kunden hoffen: Hohe Wechselbereitschaft, wenn Service stimmt', Börsen-Zeitung, vol. 182 , p. 3 .

[49] Fischer, T. (2019b) 'Für die Filiale ist auch in Zukunft Platz: Die Verbünde brechen eine Lanze für Niederlassungen, Börsen-Zeitung, vol. 99, p. 3.

[50] Fischer, T. (2019c) 'Für Kunden ist Datenfreigabe eine Frage des Preises: Viele Verbraucher würden für finanzielle Vorteile mehr über sich preisgeben, Börsen-Zeitung, vol. 131, p. 5.

[51] Flesch, J.-R. and Kohlleppel, L. (2019) 'Eine Welt ohne Banken?', $Z f g K$, vol. 14, pp. 708-711.

[52] Frank, B. and Mihm, O. (2018) 'Das Kundenerlebnis entscheidet', BankInformation, vol. 07, pp. 12-16.

[53] Freiling, I. (2019) 'Digitale Kundenplattformen: ein Überblick', $Z f g K$, vol. 18, pp. 936-940.

[54] Fürderer, K. (2016) 'Ohne Beratungsqualität kein nachhaltiger Erfolg', in Hellenkamp, D. and Fürderer, K. (ed.) Handbuch Bankvertrieb: Theorie und Praxis im Zukunftsdialog, Wiesbaden: Springer Gabler.

[55] Galla, T. (2019) Experten-Roundtable Kundenbindung: Banken und Sparkassen als digitale Lebensbegleiter, [Online], Available: https://blog.starfinanz. de/experten-roundtable-banken-und-sparkassen-als-digitaler-lebensbegleiter/ [3 Jan 2020].

[56] Gallup (2019) Umfrage zur Kundenbindung von Banken in Deutschland, [Online], Available: https://de.statista.com/statistik/daten/studie/156865/umfrage/kundenbindung-der-banken/ [3 Jan 2020].

[57] Gelbrich, K., Wünschmann, S. and Müller, S. (2018) Erfolgsfaktoren des Marketing, $2^{\text {nd }}$ edition, München: Vahlen.

[58] Gensch, A. and Müller, F. (2019) FinTechs schaffen durch die Analyse ihrer Kundendaten Transparenz und bessere Produkte, in Smolinski, R., Gerdes, M., Siejka, M. and Bodek, M.C. (ed.) Innovationen und Innovationsmanagement in der Finanzbranche, Wiesbaden: Springer Gabler.

[59] Godenrath, B. (2013) 'Privatkundengeschäft im Strukturwandel unter Druck: Knallharter Verdrängungswettbewerb und flache Zinskurve lassen Erträge schrumpfen', Börsen-Zeitung, vol. 135, p. 5.

[60] Godenrath, B. (2014) 'Filialschließung kaum ein Grund für Bankenwechsel, Börsen-Zeitung, vol. 120, p. 4.

[61] Godenrath, B. (2016) 'Die Rolle des COO in Banken wird aufgewertet: Aufgabenfülle des Chief Operating Officer wächst', Börsen-Zeitung, vol. 18, p. 5.

[62] Godenrath, B. (2017) 'Alle Kanäle bespielen: Banken ringen mit Folgen ihrer Digitalisierung', Börsen-Zeitung, vol. 98, p. 5. 
[63] Godenrath, B. (2019) 'Digitalbanken erkämpfen sich Marktanteile: Lizensierte Start-ups führen vor, wie groß das Kundenbedürfnis für volldigitales und günstiges Direktbanking ist', Börsen-Zeitung, vol. 193, p. 4.

[64] Grandke, G. (2019) 'Sparkassen: Modell mitZukunft', ZfgK, vol. 10, pp. 494-495.

[65] Griese, K.-M. (2002) Der Einfluss von Emotionen auf die Kundenzufriedenheit: Ansätze für ein erfolgreiches Consumer Relationship Marketing mit 18- bis 25-jährigen Bankkunden, Wiesbaden: Springer Gabler.

[66] Grigo, J. (2019) 'Bigtechs werden auch Bankdienstleistungen anbieten', bank und markt, vol. 01, p. 20-22.

[67] Grimm, S. and Volk, L. (2005) 'Prozessportale und Multi Channel Management', in Petzel, E. (ed.) E-Finance: Technologien, Strategien und Geschäftsmodelle, Wiesbaden: Springer Gabler.

[68] Gröppel-Klein, A., Königstorfer, J. and Terlutter, R. (2017) Verhaltenswissenschaftliche Aspekte der Kundenbindung, in Bruhn, M. and Homburg, C. (ed.) Handbuch Kundenbindungsmanagement: Strategien und Instrumente für ein erfolgreiches CRM, Wiesbaden: Springer Gabler.

[69] Grohmann, M., Heumann, C. and Wangenheim, F. (2017) 'Determinanten der Kundenbindung', in Bruhn, M. and Homburg, C. (ed.) Handbuch Kundenbindungsmanagement: Strategien und Instrumente für ein erfolgreiches CRM, Wiesbaden: Springer Gabler.

[70] Gros, J. (2019) 'Infrastruktur an das Nachfrageverhalten anpassen: Filiale wird nach wie vor von vielen als zentraler Kontaktpunkt geschätzt', BörsenZeitung, vol. 63, p. B3.

[71] Guindos, L. (2019) Challenges for bank profitability, [Online], Available: https://www.bis.org/review/r190502a.pdf [3 Jan 2020].

[72] Hambrecht, M. and Shefer, S. (2019) Neue Schlagkraft für Banken: Team Mensch-Maschine, [Online], Available: https://www.accenture.com/_acnme$\mathrm{dia} /$ pdf-89/accenture-workforce-banking-survey-report-2018.pdf [3 Jan 2020].

[73] Hanreich, W. (2006) 'Ganzheitliche Beratung bei Banken als Kundenbindungsinstrument', in Effert, D. and Hanreich, W. (ed.) Ganzheitliche Beratung bei Banken: Modeerscheinung oder Erfolgskonzept, Wiesbaden: Springer Gabler.

[74] Hastenteufel, J. (2018) Definition Kundenbindung, in: Gabler Banklexikon, [Online], Available: https:/www.gabler-banklexikon.de/definition/kundenbindung-59461 [3 Jan 2020].

[75] Hellenkamp, D. (2016) 'Generation Y: Bankkunden im Zeitalter der Digitalisierung', in Hellenkamp, D. and Fürderer, K. (ed.) Handbuch Bankvertrieb: Theorie und Praxis im Zukunftsdialog, Wiesbaden: Springer Gabler.

[76] Helmke, S., Uebel, M. and Dangelmaier, W. (2017) 'Grundlagen und Ziele des CRM-Ansatzes', in Helmke, S., Uebel, M. and Dangelmaier, W. (ed.) Effektives Customer Relationship Management: Instrumente, Einführungskonzepte, Organisation, Wiesbaden: Springer Gabler.

[77] Hepp, C. (2008) Fehler- und Fehlerfolgekosten in Banken: Messung und Steuerung der internen Dienstleistungsqualität, Wiesbaden: Springer Gabler. 
What do German bank customers want? The importance of customer expectations...

[78] Hille, L. (2018) 'Banken zwischen Regulierung und Digitalisierung: Geschäftsmodelle unter Stress', in Böhnke, W. and Rolfes, B. (ed.) Neue Erlösquellen oder Konsolidierung?: Geschäftsmodelle der Banken und Sparkassen auf dem Prüfstand, Wiesbaden: Springer Gabler.

[79] Holböck, J. (2006) 'Wie profitabel ist die ganzheitliche Finanzberatung?', in Effert, D. and Hanreich, W. (ed.) Ganzheitliche Beratung bei Banken: Modeerscheinung oder Erfolgskonzept, Wiesbaden: Springer Gabler.

[80] Holtermann, F. and Atzler, E. (2019) Finanzaufsicht: IT-Probleme bei Banken, [Online], Available: https:/www.handelsblatt.com/finanzen/banken-versicherungen/finanzaufsicht-it-probleme-bei-banken-zahl-der-beschwerden-nimmtdeutlich-zu/25052900.html [3 Jan 2020].

[81] Homburg, C., Becker, A. and Hentschel, F. (2017) 'Der Zusammenhang zwischen Kundenzufriedenheit und Kundenbindung', in Bruhn, M. and Homburg, C. (ed.) Handbuch Kundenbindungsmanagement: Strategien und Instrumente für ein erfolgreiches CRM, Wiesbaden: Springer Gabler.

[82] Homburg, C. and Bucerius, M. (2016) 'Kundenzufriedenheit als Managementherausforderung', in Homburg, C. (ed.) Kundenzufriedenheit: Konzepte, Methoden, Erfahrungen, $9^{\text {th }}$ edition, Wiesbaden: Springer Gabler.

[83] Homburg, C. and Stock-Homburg, R. (2016) 'Theoretische Perspektiven zur Kundenzufriedenheit', in Homburg, C. (ed.) Kundenzufriedenheit: Konzepte, Methoden, Erfahrungen, $9^{\text {th }}$ edition, Wiesbaden: Springer Gabler.

[84] Ili, S. and Lichtenthaler, U. (2017) 'Das Ende des traditionellen Bankenwesens? Hoffentlich!', in Smolinski, R., Gerdes, M., Siejka, M. and Bodek, M.C. (ed.) Innovationen und Innovationsmanagement in der Finanzbranche, Wiesbaden: Springer Gabler.

[85] Inhoffen, L. (2019) Nur die Hälfte der Deutschen sieht einen Unterschied zwischen ihrer Hauptbank und anderen Banken, [Online], Available: https:// yougov.de/news/2019/02/12/nur-die-halfte-der-deutschen-sieht-einen-unterschi/ [3 Jan 2020].

[86] Jentsch, S. (2016) 'Banken-Technologie: Anforderungen an die Bank der Zukunft', in Hellenkamp, D. and Fürderer, K. (ed.) Handbuch Bankvertrieb: Theorie und Praxis im Zukunftsdialog, Wiesbaden: Springer Gabler.

[87] Judex, O. (2019) 'Kunden dürfen sich nicht verarscht fühlen', Trend, vol. 40, pp. 80-83.

[88] Kautz, C.I. (2018) 'Persönliche Beratung hat sich weiterentwickelt', BörsenZeitung, vol. 188, p. 4.

[89] Keck, M. and Hahn, M. (2006) Integration der Vertriebswege: Herausforderung im dynamischen Retail Banking, Wiesbaden: Springer Gabler.

[90] Kemmer, M. (2017) 'Banken im Zugzwang, Banken im Aufbruch: Freier und fairer Wettbewerb auf einem heterogenen und stabilen Markt garantiert die besten Resultate für Kunden wie auch die Gesamtwirtschaft', Börsen-Zeitung, vol. 67 , p. B6. 
[91] Kirmße, S. (2017) 'Die Entwicklungen europäischer Banken im Spannungsfeld von Niedrigzins, Regulierung und Digitalisierung', in Kaluza, B. et al. (ed.) Betriebswirtschaftliche Fragen zu Steuern, Finanzierung, Banken und Management, Wiesbaden: Springer Gabler.

[92] Kiss, H.F. and Vuckovic, G. (2019) 'Managemententwicklungen und Digitalisierung: Den eigenen Personalbestand vorausschauend pflegen', Die Bank, vol. 07, pp. 72-77.

[93] Klein, M. (2010) 'Ganzheitliche Beratung oder Produktverkauf: ein Widerspruch?!', in Effert, D. (ed.): Qualitäts- und Preisimage bei Banken: Strategien zu mehr Ertrag, Wiesbaden: Springer Gabler.

[94] Kleine, J. and Jolmes, M. (2019) 'Smart Channel Banking: Neue Konturen für die Zukunft der Bank', ZfgK, vol. 05, pp. 242-247.

[95] Klink, O. (2019) 'Nachhaltigkeit verlangt Investitionen: Sparkassen denken und handeln langfristig', Börsen-Zeitung, vol. 42, p. B9.

[96] Köllnberger, J., Sander, Ch., Wiederkehr, V., Rottenaicher, S. and Rennhak C. (2014) Ergebnisse einer Marktstudie zur Kundenbindung im Retail Banking, [Online], Available: https://www.esb-business-school.de/fileadmin/user_upload/Fakultaet_ESB/Forschung/Publikationen/Diskussionsbeitraege_zu_Marketing_Management/2014-1-Reutlinger_Diskussionsbeitrag_2014_-_ $\overline{1}$.pdf [3 Jan 2020].

[97] Kolak, M. (2018) Auch die Bank in der Hosentasche kann Kundennähe bedeuten, [Online], Available: https://veranstaltungen.handelsblatt.com/bankengipfel/auch-die-bank-in-der-hosentasche-kann-kundennaehe-bedeuten/ [3 Jan 2020].

[98] Kotler, P., Keller, K.L. and Opresnik, M.O. (2017) Marketing-Management: Konzepte, Instrumente, Unternehmensfallstudien, $15^{\text {th }}$ edition, Hallbergmoos: Pearson Verlag.

[99] KPMG (2013) Financial Services - Auswirkungen regulatorischer Anforderungen: Studie, [Online], Available: https://www.fundresearch.de/fundresearch-wAssets/sites/default/files/Nachrichten/Top-Themen/2013/Bro-BDBStudie_11-13.pdf [3 Jan 2020].

[100] Krafft, M. (1999) 'Der Kunde im Fokus: Kundennähe, Kundenzufriedenheit, Kundenbindung und Kundenwert?', $D B W$, vol. 04, pp. 511-530.

[101] Krafft, M. (2007) Kundenbindung und Kundenwert, $2^{\text {nd }}$ edition, Heidelberg: Physica-Verlag.

[102] Krafft, M. and Götz, O. (2011) 'Der Zusammenhang zwischen Kundennähe, Kundenzufriedenheit und Kundenbindung sowie deren Erfolgswirkungen', in Hippner, H., Hubrich, B. and Wilde, K.-D. (ed.) Grundlagen des CRM: Strategie, Geschäftsprozesse und IT-Unterstützung, Wiesbaden: Springer Gabler, $3^{\text {rd }}$ edition.

[103] Kuhn, W. (2015) 'Fehlendes Vertrauen kann sich heute keine Bank mehr leisten: Qualität ist kein Zufall, sondern Ergebnis vorgelagerter Prozesse und gelungener menschlicher Interaktion', Börsen-Zeitung, vol. 36, p. B8. 
What do German bank customers want? The importance of customer expectations...

[104] Kuhn, W. (2016) 'Die kluge Kombination von Mensch und Maschine bestimmt den Erfolg der Banken: Heute kommt es darauf an, beide Welten im Sinne der Kunden zu verknüpfen', Börsen-Zeitung, vol. 68, p. B6.

[105] Leichsenring, H. (2017) Auch der digitale Bankkunde will beraten werden: Vier Handlungsempfehlungen für Banken, [Online], Available: https://www. der-bank-blog.de/auch-der-digitale-bankkunde-will-beraten-werden/studien/ kundenorientierung-banking/24900/ [3 Jan 2020].

[106] Leichsenring, H. (2018) Finanzinstitute müssen vor GAFAs keine Angst haben, [Online], Available: https://www.der-bank-blog.de/finanzinstitutegafas-angst/retail-banking/32684/ [3 Jan 2020].

[107] Leichsenring, H. (2019a) BigTechs greifen die Banken an, [Online], Available: https://www.der-bank-blog.de/bigtechs-greifen-die-banken-an/ lesenswert/37658894/ [3 Jan 2020].

[108] Leichsenring, H. (2019b) Fünf erfolgskritische Herausforderungen für Banken: Banken vor der strategischen Transformation, [Online], Available: https://www.der-bank-blog.de/fuenf-herausforderungen-banken/studien/ banking-trends/37655662/ [3 Jan 2020].

[109] Leichsenring, H. (2019c) Ist Ihre Bank wirklich kundenorientiert?: 10 Eigenschaften eines kundenzentrierten Unternehmens, [Online], Available: https://www.der-bank-blog.de/ist-ihre-bank/customer-experience/37658919/ [3 Jan 2020].

[110] Lenz, R. (2015) 'Banking 2025: Die Bank der Zukunft, BFuP, vol. 05, pp. 509-529.

[111] Lieberknecht, J. (2019a) 'Digitalisierung und Regulierung: Katalysatoren eines sich wandelnden Bankgeschäftes', in Hellenkamp, D. and Fürderer, K. (ed.) Handbuch Bankvertrieb: Theorie und Praxis im Zukunftsdialog, Wiesbaden: Springer Gabler.

[112] Lieberknecht, J. (2019b) 'Persönlich oder digital? Beides!: Trotz Digitalisierung', Börsen-Zeitung, vol. 98, p. B8.

[113] Lister, M. (2018) 'Die Perspektiven deutscher Kreditinstitute unter dem Druck von Niedrigzinsen, Regulierung und Digitalisierung', in Böhnke, W. and Rolfes, B. (ed.) Neue Erlösquellen oder Konsolidierung?: Geschäftsmodelle der Banken und Sparkassen auf dem Prüfstand, Wiesbaden: Springer Gabler.

[114] Mang, T. (2015) 'Persönliche Nähe zu den Kunden macht Sparkassen aus: Das ist heute und auch morgen ihr Mehrwert', Börsen-Zeitung, vol. 105, p. B2.

[115] Meffert, H., Bruhn, M. and Hadwich, K. (2018) Dienstleistungsmarketing: Grundlagen, Konzepte, Methoden, $9^{\text {th }}$ edition, Wiesbaden: Springer Gabler.

[116] Meinl, H., Nedjelik, M., Hartl, S., and Lehr-Splawinski, K. (2016) Digitalisierung im Bankgeschäft: Wie persönlich soll Beratung heute noch sein?, [Online], Available: https://www.baningo.com/whitepapers/Digitalisierung\%20im\% 20Bankgeschäft\%20-\%20aktuelle\%20Studienergebnisse.pdf [3 Jan 2020]. 
[117] Mengue Nkoa, C.U. (2006) Effiziente Gestaltung bankspezifischer CRM-Prozesse: Ein praxisorientiertes Referenz-Organisationsmodell, Wiesbaden: Springer Gabler.

[118] Meyer, T. (2016) Die nächste Bankenkrise, [Online], Available: https://www. faz.net/aktuell/wirtschaft/mayers-weltwirtschaft/mayers-weltwirtschaft-dienaechste-bankenkrise-14332670.html [3 Jan 2020].

[119] Mihm, O. (2014) 'Wandel aktiv gestalten, bevor es andere tun: Sparkassen müssen Mehrwert besser transportieren', Börsen-Zeitung, vol. 79, p. B7.

[120] Mihm, O. (2019) 'Junge Berufstätige wollen nicht per Telefon angesprochen werden', Bankmagazin, vol. 10, p. 14.

[121] Mihm, O. and Jacobs, B. (2012) 'Für jeden Kunden die passende Bank', Die Bank, vol. 09, pp. 21-25.

[122] Mihm, O. and Jacobs, B. (2017) 'Ohne den Kunden geht es nicht', BankInformation, vol. 08, pp. 12-15.

[123] Mihm, O. and Wollmann, T. (2018) IM-Privat- und Geschäftskundenstudie 2018: Das Kundenerlebnis entscheidet, [Online], Available: https:/www. investors-marketing.de/data/immc/media/doc/IM-Studie-2018_Expose_u_ Bestellform.pdf [3 Jan 2020].

[124] Moormann, J. (2001) 'Bankvertrieb im digitalen Zeitalter', in Moormann, J. and Roßbach, P. (ed.) Customer Relationship in Banken, Frankfurt am Main: Bankakademie.

[125] Muller, C. (2019) Bankenplatz in der Defensive: Gespräch mit Serge de Cillia, Direktor der Bankenvereinigung ABBL, [Online], Available: http://www. tageblatt.lu/headlines/bankenplatz-in-der-defensive-serge-de-cillia-direktorder-bankenvereinigung-abbl-im-gespraech/ [3 Jan 2020].

[126] Murray, B. (2019) 'Die Zukunft der Banken: spezialisieren oder kooperieren?', bank und markt, vol. 08, pp. 20-22.

[127] Neubacher, B. (2014) 'In die Zange genommen: Die Erträge lahmen, die Kosten nehmen zu', Börsen-Zeitung, vol. 154, p. 5.

[128] Neubacher, B. (2019a) 'Der Finanzsektor wird neu vermessen: Der digitale Umbruch wird zunehmend Realität', Börsen-Zeitung, vol. 143, p. 2.

[129] Neubacher, B. (2019b) 'Europas Banken werden abgehängt: Weltweite Wertschöpfung im Sektor nimmt im zweiten Jahr in Folge ab, schreibt die Beratungsfirma BCG', Börsen-Zeitung, vol. 59, p. 2.

[130] Neuhaus, D. (2018) 'Neuartige Kundenerlebnisse durch digitale Ökosysteme: Substanzielle Effizienzpotenziale ausschöpfen', Börsen-Zeitung, vol. 82, p. B7.

[131] n.u. (2019a) 'Bankenaufsicht: Sorgenfalten', $Z f g K$, vol. 10, p. 4.

[132] n.u. (2019b) 'Bankprodukte: Kunden wollen Zusatzangebote', Die Bank, vol. 08, p. 6.

[133] n.u. (2019c) 'Befragung von Top-Entscheidern: Kritik an fehlender Kundenorientierung', Die Bank, vol. 06, p. 6. 
What do German bank customers want? The importance of customer expectations...

[134] n.u. (2019d) 'Filialbanken: An den Kunden vorbei?', bank und markt, vol. 03 , p. 4.

[135] n.u. (2019e) Geldabheben mit Blick auf die Uhr: Banken machen Gebühren von Tageszeit abhängig, [Online], Available: https:/www.n-tv.de/mediathek/ videos/wirtschaft/Banken-machen-Gebuehren-von-Tageszeit-abhaengig-article21434733.html [3 Jan 2020].

[136] n.u. (2019f) 'Kampagne gegen Provisionen trägt Früchte: Anleger misstrauen der Beratung', bank und markt, vol. 06, p. 271.

[137] n.u. (2019g) 'Messenger in der Finanzbranche: Kundenservice per App', Die Bank, vol. 06, p. 6.

[138] n.u. (2019h) 'Privatkundengeschäft: Investitionen verbessern Kundenzufriedenheit', bank und markt, vol. 10, pp. 7-8.

[139] n.u. (2019i) 'Jede zehnte Bank von der Schließung bedroht', Die Bank Newsletter für Bankpolitik und Praxis (05.06.2019), p. 7.

[140] Oberle, S., Hein, H. and Lahmann, M. (2016) Bankberatung der Zukunft: Die Chancen der Digitalisierung im Retail Banking nutzen, [Online], Available: https://www.soprasteria.de/docs/librariesprovider33/Studien/bankberatungder-zukunft-2016.pdf [3 Jan 2020].

[141] Pade, R. and Bruch, D. (2016) 'Aufholjagd in der Digitalisierung', Die Bank, vol. 04, pp. 52-55.

[142] Popp, N. (2019) Die Bankfiliale wird zum digitalen Hub, [Online], Available: https://www.geld-digital.de/news/bankfiliale-digitalen-hub/ [3 Jan 2020].

[143] Poppensieker, T. and Schröck, G. (2017) 'Völlig neues Risikomanagement in Banken bis 2025', Börsen-Zeitung, vol. 74, p. 6.

[144] Protiviti (2016) Getting to the Heart of Customer Experience, [Online], Available: https://www.protiviti.com/sites/default/files/united_states/insights/ getting-to-heart-of-customer-experience-protiviti.pdf [3 Jan 2020].

[145] Quadient (2017) Umfragebericht von Quadient: Die 4 treibenden Kräfte hinter jeder Customer Experience Strategie, [Online], Available: https:// de.quadient.com/de/resources/die-4-treibenden-kraefte-hinter-jeder-customer-experience-strategie [3 Jan 2020].

[146] Quadient (2019) Das Erfolgsrezept: konsistente Kundendaten und eine Omnichannel-Strategie, [Online], Available: https://de.quadient.com/de/resources/das-erfolgsrezept-konsistente-kundendaten-und-eine-omnichannelstrategie [3 Jan 2020].

[147] Rankel, R. (2016) 'Empfehlungsmarketing als optimaler Weg zu neuen Bankkunden', in Hellenkamp, D. and Fürderer, K. (ed.) Handbuch Bankvertrieb: Theorie und Praxis im Zukunftsdialog, Wiesbaden: Springer Gabler.

[148] Rega, I. (2019) 'Firmenkundengeschäft erfährt Belebung und Frische: Kombination neuer digitaler Möglichkeiten mit traditionell ausgerichteten Werten ermöglicht konsequente Positionierung als genossenschaftlicher Partner', Börsen-Zeitung, vol. 92, p. B10. 
[149] Reichheld, F.F. (1997) Der Loyalitäts-Effekt: Die verborgene Kraft hinter Wachstum, Gewinnen und Unternehmenswert, Frankfurt am Main: Campus.

[150] Reittinger, W.J. (2019) 'Ganzheitliche Beratungslösungen im Private Banking', in Brost, H., Faust, M. and Reittinger, W.J. (ed.) Private Banking und Wealth Management: Strategien und Erfolgsfaktoren, Wiesbaden: Springer Gabler, $3^{\text {rd }}$ edition.

[151] Rennhak, C., Halfmann, M. and Numberger, S. (2005) Kundenbindung bei Banken: Status Quo und Ausblick, [Online], Available: https:/www. munich-business-school.de/fileadmin/mbs_daten/dateien/working_papers/ mbs-wp-2005-04.pdf [3 Jan 2020].

[152] Richter-Mundani, S. (1999) Kundenbindungssysteme für Kreditinstitute: Der Zusammenhang von Kundenorientierung, Dienstleistungsqualität und Beschwerdemanagement, Wiesbaden: Springer Gabler.

[153] Rohrmeier, D. (2019) 'Qualifikationen für das Bankgeschäft von morgen: Konsequenter Blick auf die Kundenerwartungen hilft, sich auf das Wesentliche zu konzentrieren, ohne nötige Spezialqualifikationen zu vernachlässigen', Börsen-Zeitung, vol. 100, p. B5.

[154] Ronzal, W. (2006) 'Woran scheitern Beratungskonzepte?', in Effert, D. and Hanreich, W. (ed.) Ganzheitliche Beratung bei Banken: Modeerscheinung oder Erfolgskonzept, Wiesbaden: Springer Gabler.

[155] Rudegeair, P. and Hoffmann, L. (2019) Next in Google's Quest for Consumer Dominance: Banking, [Online], Available: https:/www.wsj.com/articles/next-in-googles-quest-for-consumer-dominancebanking-11573644601 [3 Jan 2020].

[156] Salesforce (2018) State of the Connected Costumer: Einblicke aus einer Umfrage unter mehr als 6.700 End- und Geschäftskunden am Schnitpunkt von Customer Experience, Technologie und Vertrauen, $2^{\text {nd }}$ edition, [Online], Available: https://c1.sfdcstatic.com/content/dam/web/de_de/www/PDF/ SoCC_2018\%20_16_SP_DE.pdf [3 Jan 2020].

[157] Scherber, P. (2019) In vielen Banken ist eine ganzheitliche Beratung noch nicht der Standard, [Online], Available: https:/www.bankingclub.de/news/ vertrieb/in-vielen-banken-ist-eine-ganzheitliche-beratung-noch-nicht-derstandard/ [3 Jan 2020].

[158] Schimpf, M. (2018) Deutschlands Banken stecken in einer schweren Vertrauenskrise: Kundenerwartung im Omnikanal-Umfeld, [Online], Available: https://www.der-bank-blog.de/deutschlands-banken-vertrauenskrise/ kundenbedarf/31911/ [3 Jan 2020].

[159] Schleidt, D. (2019) Undurchsichtige Kontomodelle - Niedrige Zinsen, versteckte Kosten, [Online], Available: https://www.faz.net/aktuell/rhein-main/ wirtschaft/niedrige-zinsen-versteckte-kosten-16432733.html [3 Jan 2020].

[160] Schneider, K. (2019) Das gute Gedächtnis von Alexa und Co. - Was Sprachassistenten heute bieten und Verbraucher wissen müssen, Handelsblatt, Nr. 193 vom 08.10.2019, p. 34. 
What do German bank customers want? The importance of customer expectations...

[161] Schrader, J. (2019) 'Revolution in engen Grenzen: Smartphones stellen den Kontakt zum Kunden auf neue Füße, doch bei alltäglichen Zahlungen pflegt die Technik ein Nischendasein', Börsen-Zeitung, vol. 99, p. 3.

[162] Schuster, H. and Hastenteufel, J. (2019) Bankenbranche im Wandel, $2^{\text {nd }}$ edition, Baden-Baden: Nomos.

[163] Seidl, P. (2017) 'Reputation in der Finanzbranche: Innovationen als unterschätzter Erfolgsfaktor: Besonderheiten von Banken, FinTechs und Online-Reputation', in Smolinski, R., Gerdes, M., Siejka, M. and Bodek, M.C. (ed.) Innovationen und Innovationsmanagement in der Finanzbranche, Wiesbaden: Springer Gabler.

[164] Serra, A. (2018) Kundenbindung im digitalen Zeitalter, [Online], Available: https://blog.gft.com/de/2018/01/02/kundenbindung-im-digitalen-zeitalter/ [3 Jan 2020].

[165] Simmank, J. (2019) Google möchte Girokonto anbieten, [Online], Available: https:/www.zeit.de/wirtschaft/geldanlage/2019-11/google-girokontenfinanzdienstleistungen-bank-citigroup [3 Jan 2020].

[166] Sinn, W. and Schmundt, W. (2016) Deutschlands Banken 2016: Die Stunde der Entscheider, [Online], Available: https://www.bain.com/contentasse ts/7857d773569343949df3f77e7e6ba86d/bain-studie_deutschlands_banken_2016_ds_final.pdf [3 Jan 2020].

[167] Sinn, W. and Schmundt, W. (2017) Deutschlands Banken 2017: Metamorphose im laufenden Betrieb, [Online], Available: https:/www.bain.com/ contentassets/b48fc2570a36401bb131bc6180a63460/bain-studie_deutschlands-banken-2017_final.pdf [3 Jan 2020].

[168] Sinn, W. and Schmundt, W. (2018) Deutschlands Banken 2018: Schneller, stärker... und rentabler?, [Online], Available: https:/www.bain.com/cont entassets/4a1a0a5acb694e89abc6d227c25526cf/bain-studie_deutschlandsbanken2018_vf.pdf [3 Jan 2020].

[169] Sleegers, A. (2018) 'Stabilität gibt es nicht gratis', Börsen-Zeitung, vol. 244, p. 6.

[170] Sleegers, A. (2019) 'Der Negativzins wird salonfähig: Die deutschen Institute verdienen an Kundeneinlagen in der Summe mehr, als sie dafür zahlen', Börsen-Zeitung, vol. 183, p. 3.

[171] Spiwoks, M. (2003) 'Kundenbindung als Schlüssel zu höherer Ertragskraft im Vermögensverwaltungsgeschäft', Die Bank, vol. 09, pp. 590-593.

[172] Splendid Research (2019) Umfrage zur Häufigkeit eines Bankwechsels der Kunden von Filialbanken 2019, [Online], Available: https://de.statista. com/statistik/daten/studie/977162/umfrage/umfrage-zur-haeufigkeit-einesbankwechsels-der-kunden-von-filialbanken/ [3 Jan 2020].

[173] Stock-Homburg, R. (2016) 'Kundenorientierte Mitarbeiter als Schlüssel zur Kundenzufriedenheit', in Homburg, C. (ed.) Kundenzufriedenheit: Konzepte, Methoden, Erfahrungen, $9^{\text {th }}$ edition, Wiesbaden: Springer Gabler. 
[174] Stollarz, M. (2018) 'Digitalisierung in der Finanzbranche ist kein Selbstzweck', Börsen-Zeitung, vol. 82, p. B5.

[175] Stoltenberg, S. (2017) 'Regionale Stärke für die Zukunft: Sparkassen setzen auf die Verbindung von Präsenz in der Fläche mit digitalen Angeboten', Börsen-Zeitung, vol. 121, p. 4.

[176] Streim, A., Grigo, J. and Nadler, F. (2019) Beim Online-Banking sind nur noch Senioren zurückhaltend, [Online], Available: https:/www.bitkom.org/ Presse/Presseinformation/Beim-Online-Banking-sind-nur-noch-Seniorenzurueckhaltend [3 Jan 2020].

[177] Terliesner, S. (2019) 'Wie Geldhäuser ihre inaktiven Kunden wecken', Bankmagazin, vol. 10, pp. 12-17.

[178] Thieme, J. and Schweiger, B. (2019) 'Gefährdet zu viel Transparenz das Geschäftsmodell von Banken?’, Die Bank, vol. 09, pp. 26-31.

[179] Thole, F. (2019) 'Die Filiale wird künftig eine Nebenrolle spielen', bank und markt, vol. 06, pp. 269-271.

[180] Vater, D. and Bergmann, M (2015) 'Die Zukunft gehört dem Omnikanal', $Z f g K$, vol. 06, pp. 289-292.

[181] Vishnoi, L. (2019) 5 Ways the Financial Services Industry Is Adapting to Customer Expectations in 2019, [Online], Available: https://acquire.io/blog/ financial-services-industry-customer-expectations/ [3 Jan 2020].

[182] Vogelgesang, H. (2015) 'Die Zukunft der Filiale: nahe am Menschen', $Z f g K$, vol. 14, pp. 711-712.

[183] Waidelich, M. (2015) 'Digitalisierung als neuer Weg zur Kundenbindung', Börsen-Zeitung, vol. 178, p. 2.

[184] Wannhoff, J. (2018) 'Digitalisierung und Fintechs: das traditionelle Bankgeschäft im Wandel', in Böhnke, W. and Rolfes, B. (ed.) Neue Erlösquellen oder Konsolidierung?: Geschäftsmodelle der Banken und Sparkassen auf dem Prüfstand, Wiesbaden: Springer Gabler.

[185] Waschbusch, G., Reinstädtler, G. and Ruffing, M. (2018) 'Aktuelle Ertragslage von Banken: Belastungsfaktoren und Wege aus der Ertragskrise', $Z f g K$, vol. 18, pp. 916-921.

[186] Waschbusch, G., Rolle, A. and Berg, S. (2018) 'Herausforderungen für Banken durch das Niedrigzinsumfeld: Eine Analyse des Zinsüberschusses anhand der Marktzinsmethode', ÖBA, vol. 06, pp. 418-428.

[187] Weber, J. (2018) Definition Deckungsbeitrag, in: Gabler Wirtschaftslexikon, [Online], Available: https://wirtschaftslexikon.gabler.de/definition/deckungsbeitrag-27166 [3 Jan 2020].

[188] Weidmann, J. (2017) Herausforderungen für den Bankensektor, [Online], Available: https://bankenverband.de/media/files/Rede_Weidmann.pdf [3 Jan 2020].

[189] Weigl, M. (2001) 'Digital Customer Care: oder das digitale Königreich für Kunden', in Moormann, J. and Roßbach, P. (ed.) Customer Relationship in Banken, Frankfurt am Main: Bankakademie. 
What do German bank customers want? The importance of customer expectations...

[190] Weißer, N. and Zdrzalek, L. (2016) 'Banking 2020: Nur neue Wege sichern neue Erfolge', in Diab, Z. and Everling, O. (ed.) Rating von Finanzinstituten: Banken und Finanzdienstleister richtig beurteilen, Wiesbaden: Springer Gabler.

[191] Wenzel, O. (2017) NCR-Studie: Kunden erwarten mehr von ihrer Bank, [Online], Available: https://www.ncr-news.de/2017/10/24/ncr-studie-kundenerwarten-mehr-von-ihrer-bank/ [3 Jan 2020].

[192] Werne, J. (2019) 'Chancen und Risiken von KI für die Finanzbranche', bank und markt, vol. 06, pp. 265-268.

[193] Wildner, G. (2006) 'Mehr als ein Slogan?', in Effert, D. and Hanreich, W. (ed.) Ganzheitliche Beratung bei Banken: Modeerscheinung oder Erfolgskonzept, Wiesbaden: Springer Gabler.

[194] Wilken, R. and Liehr, H. (2017) 'Auf dem Weg zum digitalen Ökosystem: Robo-Advisor gleicht Anfragen von Kunden mit Fördermöglichkeiten ab, Börsen-Zeitung, vol. 119, p. B4.

[195] Witte, A. (2019) Negativzinsen ohne Freibetrag - Erste Bank erhebt Strafzinsen ab 0,01 Euro, [Online], Available: https:/www.n-tv.de/ratgeber/ErsteBank-erhebt-Strafzinsen-ab-0-01-Euro-article21402591.html [3 Jan 2020].

[196] Wittkowski, B. (2019) 'Die Digitalisierung ändert alles: Degussa Bank steckt mitten in der Transformation', Börsen-Zeitung, vol. 144, p. 2.

[197] Wolberg, H.-B. (2017) 'Persönliche Nähe zählt auch in Zukunft: Digitaler Wandel stellt die genossenschaftliche Identität nicht in Frage', Börsen-Zeitung, vol. 103, p. B5.

[198] Wolf, E. (2007) Konzeption eines CRM-Anreizsystems: Konzeption eines Anreizsystems zur Unterstützung einer erfolgreichen Implementierung von Customer Relation-ship Management, 2nd edition, München/Mering: Hampp.

[199] Wolpers, M. and Appuhn, U. (2006) 'Aktive ganzheitliche Beratung in der Sparkasse: die Großbaustelle', in Effert, D. and Hanreich, W. (ed.) Ganzheitliche Beratung bei Banken: Modeerscheinung oder Erfolgskonzept, Wiesbaden: Springer Gabler.

[200] YouGov (2019) Austauschbarkeit von Geldhäusern - Wie sich Banken von anderen Geldinstituten abheben können, [Online], Available: http:/www. yougov.de/download/alleinstellungsmerkmale_banken [3 Jan 2020].

[201] Zeisl, H. (2018) 'Globale Herausforderungen für die regionalen Genossenschaftsbanken', $Z f g K$, vol. 15, pp. 783-786. 